\title{
Electronic cigarettes-A review of the physiological health effects
}

\author{
Alyssa Zucchet ${ }^{\mathrm{ab}}$ and Grégory Schmaltz ${ }^{\mathrm{a}}$ \\ ${ }^{\mathrm{a}}$ Department of Biology, University of the Fraser Valley, Abbotsford, BC V2S 7M8, Canada; ${ }^{\mathrm{b}}$ Department \\ of Medicine, University of British Columbia, Vancouver, BC V6T 1Z4, Canada \\ *Gregory.Schmaltz@ufv.ca
}

\begin{abstract}
Electronic cigarettes (ECs) are devices that are used recreationally or as smoking cessation tools, and have become increasingly popular in recent years. We conducted a review of the available literature to determine the health effects caused by the use of these devices. A heating element in the EC aerosolizes a solution of propylene glycol, glycerol, nicotine (optional), and flavouring (optional). These compounds are generally harmless on their own. However, upon heating, they produce various carcinogens and irritants. We found that concentrations of these toxicants vary significantly depending on the type of EC device, the type of EC liquid, and the smoking behaviour of the user. Exposure to these vapours can cause inflammation and oxidative damage to in vitro and in vivo cells. EC aerosol can also potentially affect organ systems and especially cardiovascular and lung function. We concluded that EC use causes acute effects on health but not as severe as those of conventional cigarettes (CCs). These devices could, therefore, be of use for smokers of CCs wishing to quit. However, as EC aerosol introduces new toxicants not found in CCs, long-term studies are needed to investigate possible chronic effects associated with EC use.
\end{abstract}

OPEN ACCESS

Key words: electronic cigarette, vaping, electronic nicotine delivery devices, acute and chronic health effects, cellular physiology, review

Citation: Zucchet A and Schmaltz G. 2017. Electronic cigarettes - A review of the physiological health effects. FACETS 2: 575-609. doi: | 0.1 I 39/facets-20 I7-00 I 4

Editor: Trevor A. Day

Received: February 14, 2017

Accepted: June 8, 2017

Published: July 18, 2017

Copyright: (c) 2017 Zucchet and Schmaltz. This work is licensed under a Creative Commons Attribution 4.0 International License (CC BY 4.0), which permits unrestricted use, distribution, and reproduction in any medium, provided the original author(s) and source are credited.

Published by: Canadian Science Publishing

\section{Introduction}

There are long lists of known risks of smoking cigarettes. Cigarette smoke contains over 4000 chemicals, many of which are serious carcinogens like arsenic or volatile organic compounds (Romagna et al. 2013; Rahman et al. 2015). These compounds cause serious cardiovascular and respiratory disease, including lung cancer, currently leading to the death of one out of every 10 adults worldwide (Romagna et al. 2013; Rahman et al. 2015). These health risks have led to the development of materials that may assist people in quitting smoking, one of which is electronic cigarettes (ECs). ECs have existed for a long period of time, as they were first patented in 1965 by HA Gilbert as a device that looked like a conventional cigarette (CC) but did not contain the carcinogens of tobacco, designed to replace the use of CCs (Romagna et al. 2013; Cervellati et al. 2014; Rahman et al. 2015). The idea of the EC did not gain momentum until a second patent of the modern EC was taken out by $\mathrm{H}$ Lik in 2003 (Romagna et al. 2013; Cervellati et al. 2014; Rahman et al. 2015). Unlike the 1965 patent, this device was marketed as a smoking cessation device as it contained nicotine to suppress the physiological desire to smoke. Similar to the 1965 patent, this device is free of the carcinogenic tar and carbon monoxide that exists in CCs (Romagna et al. 2013; Cervellati et al. 2014; Rahman et al. 2015). From there, the popularity of the EC grew, and in 2007, Ruyan, an EC manufacturing company, made 


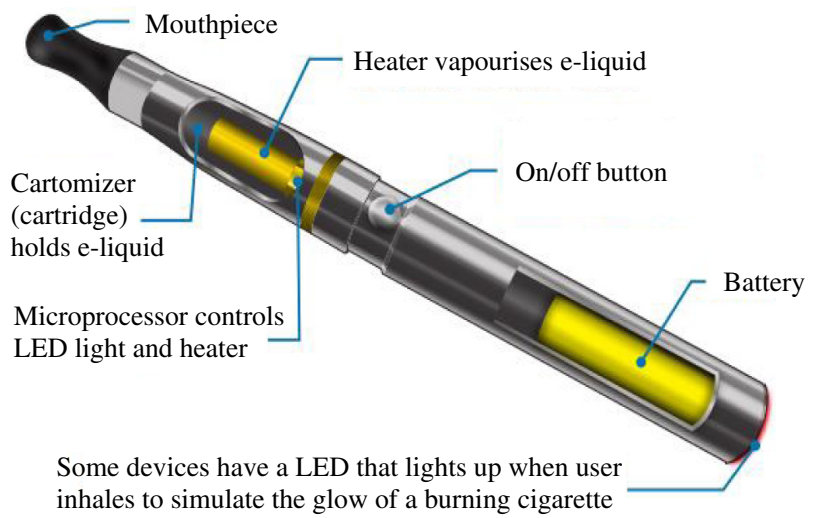

Fig. 1. Structure of an electronic cigarette (EC). ECs are made of a plastic tube, an electronic heating element, a liquid cartridge, and a battery. The rechargeable lithium battery (with or without an LED indicator) powers the heating element that heats and vapourizes the liquid in the cartridge to produce an aerosol that the user then inhales. The liquid contains solvents and optional nicotine and flavouring agents. Modified from Federal Emergency Management Agency (2014).

$\$ 127.6$ million USD from their sale (Pauly et al. 2007). The popularity of ECs has only increased since, with their use doubling in North America between 2008 and 2012 (Rahman et al. 2015). In principle, the elimination of some of the carcinogens found in CCs makes them a safer alternative to smoking, but because their popularity is fairly new, their health risks are not entirely known. Because over $98 \%$ of EC users were previous or current CC smokers (Farsalinos et al. 2014a, 2016b; Patel et al. 2016; Hammett et al. 2017), it is important to evaluate the safety of EC use in comparison with CC use.

ECs are electronic nicotine delivery devices that are shaped to look like a CC and are powered by a lithium battery (Canadian Agency for Drugs and Technologies in Health 2012; Romagna et al. 2013; Rahman et al. 2015). Specifically, ECs are made of a plastic tube, an electronic heating element, a liquid cartridge, and a battery (Fig. 1). The battery powers the heating element that heats and vapourizes the liquid in the cartridge, which the user, termed "vaper", then inhales. Depending on the type of device, the voltage and power may vary, changing the amount of vapour produced per puff (Rahman et al. 2015), as well as the inhalation toxicity of aerosolants (Leigh et al. 2016). By designing the EC to appear and work like a CC, the ergonomics appeal to the psychological aspect of smoking addiction. In addition, the optional nicotine content satisfies the physiological aspect of smoking addiction. These factors make it more likely that people will give up smoking for this "safer" device (Hajek et al. 2014). However, the question remains as to how much safer ECs are than CCs, if at all.

The main components of EC liquids are propylene glycol, which creates the artificial smoke of the EC, and glycerol (i.e., glycerin), which contains optional nicotine and flavouring agents. Glycerol and propylene glycol are classified by the Food and Drug Administration (FDA) with the label "generally recognized as safe" for ingestion. However, once heated, there is no indication as to the safety of the inhalation of these compounds or any compounds that might be produced by heat-induced degradation of these compounds. ECs also run the risk of containing toxic impurities like heavy metals or tobacco-specific nitrosamines (TSNAs). These devices remain mostly unregulated in many countries, and in others, regulation is lagging. For instance, although nicotine-containing liquids are not approved for sale by Health Canada, they are still widely available in Canada, and the federal government is still planning regulatory legislation (Czoli et al. 2015). In August 2016, the FDA introduced its first regulation for EC products and vaping shops to regulate these in the same fashion as with the tobacco industry (Food and Drug Administration 2016). However, manufacturers will still have at 
least two years to obtain regulatory approval for current products. In Europe, advertising of ECs is banned and new guidelines and quality control rules have been established recently, especially to limit nicotine concentration. Overall, most current regulatory efforts put an emphasis on enforcing limited disclosures on the industry, and do not yet focus on impacting safety or efficacy.

There is currently a gap in our understanding of the health effects of ECs. Many of the EC reviews published to date focused on the social aspects of ECs, like their success in decreasing the urge to smoke (Hajek 2014). Other reviews focused on basic health assessments like the potential risk of inhaling propylene glycol (Hajek et al. 2014; Cooke et al. 2015a; Rahman et al. 2015). Some reviews focusing on the physiological effects of ECs (e.g., Breland et al. 2014; Pisinger and Døssing 2014) relied on studies that mostly used methodologies not amenable to broad-scale conclusions (e.g., in vitro cell studies using only EC liquids and not their vapour). Given the rapidly growing research efforts on the health effects of ECs, conclusions drawn by reviews and studies need timely updating to inform best practices both in terms of regulatory action and policy making. The aim of the present review was to perform an exhaustive review of the research on the health effects of ECs. First, we examined the composition of EC devices, liquids, and vapours. Second, we looked at the effect of EC liquids and vapours at an in vitro and in vivo cellular level. Finally, we investigated the effect of EC liquids and vapours on organ systems and overall body physiology. After reviewing the field, we identified gaps in our knowledge, discussed methodological issues related to aerosol delivery, and suggested avenues for further research.

\section{Methods}

We performed a manual search of major databases such as PubMed, Google Scholar, JSTOR, SpringerLink, and ScienceDirect for relevant articles using keywords like "electronic cigarette", "e-cigarette", "electronic nicotine delivery system", "vaper", and similar variations on 31 October 2016. We also obtained relevant articles by studying the citations of the articles revealed with the database searches. We discovered over 2100 papers with these search criteria and excluded papers related to policies, regulation, or other topics that did not include biological information. This narrowed our research to a total of 962 scientific research articles relating to EC use. The articles were screened manually to assess the relevance of each. Research relating to user perception of and satisfaction with ECs was excluded as it did not relate to health effects. We focused this review on health effects due to normal use and functioning of the devices. Therefore, articles focusing on other topics such as device explosion or e-liquid ingestion were excluded. This scan led to the discovery of a subset of 175 articles that focused on physiological health effects. Given the recent research interest on the health effects of ECs and the development of new methodologies, many of the cited articles are research papers published since 2014 .

\section{Results and discussion}

\section{Composition of the EC device}

The composition of EC liquids and the devices themselves determine what the user may be exposed to and how that will affect their health. Before looking at what is in the EC liquids and, therefore, is meant to be inhaled, we should consider the hazards of EC devices themselves. EC devices often use lithium batteries to power the heating mechanisms, which are prone to leak or to cause fires or explosions. These are risks vapers rarely consider (Brown and Cheng 2014). Furthermore, the heating mechanisms of ECs are capable of emitting metallic particles such as tin, iron, lead, chromium, manganese, nickel, and cadmium, which the user then inhales (Brown and Cheng 2014; Grana et al. 2014; Mikheev et al. 2016; Hess et al. 2017). These metals are considered harmful or potentially harmful to human health by the FDA (Brown and Cheng 2014). The source of these metals is often the heating 
filaments of the devices. EC heating filaments tend to be made of nickel and chromium and coated with tin or silver (Williams et al. 2013, 2015). Tin is a friable metal and can end up in the EC aerosol in large quantities. Tin is cytotoxic to human lung fibroblasts and can cause inflammation (Williams et al. 2013, 2015). Nickel from the cartomizer is found in EC vapours at levels 2-100 times the amount found in cigarette smoke and can also contribute to lung inflammation (Williams et al. 2013). Copper nanoparticles present in EC vapour can cause elevated levels of mitochondrial reactive oxygen species (ROS), DNA damage, and lung inflammation (Lerner et al. 2016). In addition to introducing metals into the lungs, ECs contain oxidants in the batteries and cartomizers, which could also contribute to inflammation in the lungs (Lerner et al. 2015a). Thus, without even considering the EC liquid, ECs expose the users to potentially harmful substances. At least some of these substances (e.g., nickel) are not inhaled in large quantities by CC users. These recent findings warrant further research on the potential toxicity of EC devices and regulatory action on the manufacturing process (see below).

\section{Composition of the EC liquid}

Unflavoured EC liquid contains two main chemicals: propylene glycol and glycerol. These chemicals in their liquid or vapourized form do not seem to cause serious health problems. First, propylene glycol, responsible for producing the false smoke, is a suspected minor respiratory irritant causing a sore throat or cough (Grana et al. 2014). Propylene glycol was also found to decrease lung function. When aviation trainees were exposed to a propylene glycol mist, they experienced decreased forced vital capacity as well as decreased forced expiratory volume in $1 \mathrm{~s}$ (FEV1) (Wieslander et al. 2001). In one study, researchers found that one puff on a shisha pen, an EC designed to taste like a water pipe, can produce $430-630 \mathrm{mg}$ of propylene glycol per $\mathrm{m}^{3}$ of lung alveoli; enough to cause lung irritation (Kienhuis et al. 2015). Second, glycerol, which assists with the vapourization of the solution, is generally found not to be cytotoxic (Bahl et al. 2012). Some EC liquids, should the user decide, also contain nicotine. Nicotine prolongs neutrophil survival, contributes to inflammation, and causes cancer progression (Aoshiba et al. 1996; Chu et al. 2013). These cellular effects of nicotine can cause various effects at the organism level (see below). Therefore, other than risking what are probably only a minor cough and known risks of nicotine use, the hazards of EC liquids are lower than those of CCs and their various toxicants. However, once the solution is aerosolized, the risk factors change.

\section{Composition of unflavoured EC aerosols}

When EC liquid is heated to create the aerosol intended for inhalation, propylene glycol and glycerol are oxidized to produce potentially hazardous by-products, with propylene glycol being more susceptible to decomposition than glycerol (Kosmider et al. 2014; Blair et al. 2015). Some of the toxicants found in EC vapour are likely formed as by-products during thermal degradation, especially with high-powered devices (Sleiman et al. 2016). For example, Blair et al. (2015) discovered detectable levels of acetaldehyde (suspected carcinogen), acrolein (inflammatory agent), and acetone (central nervous system depressant) in EC aerosols, though in lower amounts than in CCs. Uchiyama et al. (2013) detected formaldehyde (potent carcinogen), acetaldehyde, acetone, acrolein, glyoxal (mutagen), and methylglyoxal (mutagen) in EC aerosol from nine out of $13 \mathrm{EC}$ brands tested. Some of these toxicants (e.g., glyoxals) do not appear in CC smoke (Uchiyama et al. 2013). These results are supported by other studies. For instance, Farsalinos et al. (2015b) detected formaldehyde, acetaldehyde, acetone, and acrolein in EC aerosols; Flora et al. (2016) detected formaldehyde but no acetaldehyde or acrolein in EC aerosols; and Goniewicz et al. (2015) detected formaldehyde, acetaldehyde, acrolein, and o-methylbenzaldehyde in EC aerosols. Sleiman et al. (2016) identified two other potential carcinogens in EC vapour: propylene oxide and glycidol. Other articles showed similar results, with increasing levels of toxicants when higher-powered devices were used (Laugesen 2008; McAuley et al. 2012; Goniewicz et al. 2014b; Hutzler et al. 2014; Kosmider et al. 2014; Tayyarah and Long 2014; Geiss et al. 2015; Herrington and Myers 2015; 
O'Connell et al. 2015; El-Hellani et al. 2016; Jo and Kim 2016; Leigh et al. 2016; Sleiman et al. 2016; Talih et al. 2016). The amount and types of these degradation products vary substantially in different studies, making generalizations about the health effects of ECs difficult. Additional research is required to determine if other important carcinogens are found in EC vapour. For instance, another highly carcinogenic aldehyde by-product, hemiacetal, was found in laboratory conditions when using high-voltage (5 V) devices (Jensen et al. 2015). Future studies need to investigate whether these toxicants are found in conditions that are experienced by everyday users. The concentration of these toxicants also varied based on the type of EC liquid, which affects the propylene glycol to glycerol ratio. Because glycerol boils at a higher temperature than propylene glycol, a solvent mix with a higher proportion of glycerol leads to heating elements reaching higher temperatures. The type of EC device is also important in generating higher temperatures. Higher voltage and resistance devices get hotter and produce more aerosol, which causes users to inhale more chemicals (Blair et al. 2015; Farsalinos et al. 2015b; Geiss et al. 2015). Under "dry puff" conditions, a small quantity of liquid is applied directly to the heater, essentially making the liquid much hotter than would normally occur. Under such conditions, the levels of aldehydes (e.g., formaldehyde, acetaldehyde, and acrolein) present in the aerosol equal or exceed the amounts found in CC smoke (Farsalinos et al. 2015b; Talih et al. 2016). The high level of formaldehyde is especially concerning as this compound is a potent carcinogen and is toxic to the human reproductive system (Duong et al. 2011). Formaldehyde and other carbonyls are also problematic because their concentrations can be high and correlated with the power of the device (El-Hellani et al. 2016). This is of special concern with newer generation high-powered devices. "Dry puff" conditions can occur when the power of the device is high (9-11 W), puffs on the device are long, or when the EC liquid is added directly to the heating element in a process known as "direct dripping" practiced by some EC users (Farsalinos et al. 2015d; Talih et al. 2016). "Direct dripping" is a popular method of vaping as it creates more aerosol, a stronger flavour, and a more potent "throat hit". This method potentially puts users at risk of exposing themselves to higher levels of toxicants and nanoparticles (Mikheev et al. 2016; Talih et al. 2016). Further studies, therefore, not only need to focus on EC aerosol composition but also on the power of the devices along with the modes of delivery by users. Overall, a large majority of the experiments mentioned above showed that the amounts of aldehydes and other toxicants produced by the ECs were lower than the amounts produced by CCs (Cravo et al. 2016). In addition, some EC users experience an unpleasant taste under dry puff conditions and avoid these conditions, thus limiting the likelihood of exposure to high levels of aldehydes (Farsalinos et al. 2015d). Therefore, ECs are likely to be less toxic than CCs when looking at unflavoured liquids, especially without nicotine. With regard to the risk to bystanders, the main compound that people could be exposed to by secondhand EC exposure is a small amount of nicotine (Czogala et al. 2014; Long 2014). There are, however, still gaps in knowledge for these types of cigarettes. First, the health effects of metals (see above) need to be further investigated (Hess et al. 2017). Second, like CCs, ECs produce high levels of particulate matter in their aerosol. These particles, and especially the smaller nanoparticles, can attach to chemicals found in the aerosol or in the EC liquid. This can potentially cause more damage than would otherwise occur as the particles can then settle in the lungs (Pellegrino et al. 2012; Fuoco et al. 2014; Marini et al. 2014; Schober et al. 2014; Manigrasso et al. 2015; Trassierra et al. 2015; Casanova-Cháfer et al. 2016; Mikheev et al. 2016). EC liquids with a high propylene glycol to glycerol ratio tend to produce smaller particles, and toxicants attached to these small particles are then more likely to reach alveoli and cause damage (Heyder 2004; Pellegrino et al. 2012; Long 2014; Schober et al. 2014). Further research is needed to understand better how the number and size of particles produced in EC vapour compare with CC smoke. For example, Mikheev et al. (2016) discovered that EC aerosol contains nanoparticles (11-25 $\mathrm{nm}$ in diameter) and submicron particles (96-175 $\mathrm{nm}$ diameter) in roughly equal concentrations, whereas Sosnowski and Kramek-Romanowska (2016) reported median diameters of $410 \mathrm{~nm}$. Fuoco et al. (2014) found that the amount of particulate matter in EC vapour equaled 
or exceeded the amount in CC smoke (average of $4.39 \pm 0.42 \mathrm{E} 9$ particles $/ \mathrm{cm}^{3}$ for EC and $3.14 \pm 0.61 \mathrm{E} 9$ particles $/ \mathrm{cm}^{3}$ for cigarettes), whereas Pellegrino et al. (2012) found that the amount of particulate matter in CCs exceeded that of ECs by 15 times. So far, the discussion of aerosols produced by ECs was restricted to unflavoured products. Flavoured ECs represent a large part of the EC market and bring a new suite of potential toxicants.

\section{Composition of flavoured EC liquids and aerosols}

EC liquid flavours are used to simulate the taste of CCs or to create a new experience by giving the aerosol a pleasant taste (e.g., fruity, coffee, chocolate, or cinnamon flavours). There are over 7700 unique flavours available on the market as of January 2014 (Zhu et al. 2014). Tierney et al. (2016) determined that of 30 products tested, 13 were more than $1 \%$ flavour by weight and six of 24 flavour compounds detected were aldehydes like vanillin, which are respiratory irritants. A discussion of all flavourants used in EC liquids is impractical given this high diversity of products. Here, we focus on a sample of representative flavours. Of eight different cinnamon flavoured EC liquids, Behar et al. (2014) found that the main flavouring chemicals were CAD and 2MOCA. These two toxicants inhibit transcription factors involved with immunity, inflammation, and development (Reddy et al. 2004). Behar et al. (2014) found that three of the eight cinnamon flavours tested were cytotoxic to human lung fibroblasts and human embryonic stem cells. Another popular flavouring chemical in EC liquids is diacetyl, which is used to give an artificial buttery flavour to foods like microwave popcorn. Its inhalation has been linked to the development of bronchiolitis obliterans, an obstructive respiratory disease (Shibamoto 2014). The bad press associated with diacetyl has led some companies to substitute diacetyl with acetyl propionyl or acetoin, but these two compounds could be just as hazardous as diacetyl (Farsalinos et al. 2015b). Farsalinos et al. (2015b) found that 28.3\% of 159 sweet EC flavours contained both diacetyl and acetyl propionyl and $45.9 \%$ contained one of the two. Furthermore, $47.3 \%$ of the samples that contained diacetyl and $41.5 \%$ of the samples that contained acetyl propionyl had them in levels above what is deemed safe for inhalation by the National Institute for Occupational Safety and Health, though still less than in CCs (Farsalinos et al. 2015b). Allen et al. (2016) found diacetyl in 39 of 51 flavours tested, while also finding acetyl propionyl in 23 out of 51 flavours and acetoin in 46 out of 51 flavours. Other flavouring compounds, vanillin and the chocolate flavouring 2,5-dimethylpyrazine, caused alterations in cellular physiology and compromised the ability of airway epithelial cells to maintain homeostasis (Sherwood and Boitano 2016). In another study, Higham et al. (2016) discovered other known carcinogens such as allylthiourea, 2,3-benzofuran and toxicants such as gamma-hexenoic acid, 2-methyl valeric acid, piperidine, propanal, and styrene in EC vapour extracts. Kotandeniya et al. (2015) reported the carcinogen biomarkers N-Nitrosonornicotine (NNN) and 4-(methylnitrosamino)-1-(3-pyridyl)-1butanol (NNAL) in the urine of EC users, albeit in lower amounts than with CCs. Regardless of nicotine content, e-liquid administration intraperitoneally to adult male rats led to diminished sperm density and viability, and disrupted steroidogenesis and oxidative balance (El Golli et al. 2016d). Furthermore, e-liquid seems to also affect kidney function in rats (El Golli et al. 2016c). From the previous studies, it is clear that different e-liquid flavours contain different toxicants not found in unflavoured products, and many of these compounds are not found in CCs. Furthermore, flavouring agents may promote addiction to ECs, especially in young adults and when these agents are used in conjunction with nicotine (Kim et al. 2016; Patel et al. 2016).

\section{How manufacturing can affect the composition of EC liquids and aerosols}

Many e-liquid manufacturers do not report health warnings, chemical sources, manufacturing process, exhaustive ingredient lists, or concentrations (Kong et al. 2016). ECs are capable of delivering nicotine in their vapour, with the amount of nicotine varying based on the solution, power of the 
device, or smoking topography (e.g., puff duration) (Trtchounian et al. 2010; Spindle et al. 2015; Talih et al. 2015). Various research groups have reported that EC liquids tested in their studies do not contain the same amount of nicotine claimed on the bottle by the manufacturer (Goniewicz et al. 2013, 2014a, 2015; Hahn et al. 2014; Davis et al. 2015; Lisko et al. 2015; Pagano et al. 2016). In a study by Davis et al. (2015), 8 out of 72 liquids contained less nicotine than stated and 46 out of 72 contained more nicotine than stated. In addition, Goniewicz et al. (2015) found that 19\% of 91 EC liquids from the US, South Korea, and Poland contained nicotine levels that were more than $20 \%$ different from the amount claimed by the manufacturer, and even many liquids that were labelled as "nicotine-free" contained small amounts of nicotine. Goniewicz et al. (2013) found that 300 puffs from an EC generated a significant amount of nicotine in the vapour at approximately $0.5-15.4 \mathrm{mg}$ of nicotine depending on the level of nicotine in the liquid. Inconsistencies in nicotine concentrations are of concern as there seems to be a positive correlation in most studies to date between EC liquid nicotine concentration and the amount of nicotine found in aerosols (Breland et al. 2016). Other EC liquids contain toxicants not supposed to be found in such products (Goniewicz et al. 2014a; Lisko et al. 2015). Many studies have found that EC vapours contain TSNAs (Westenberger 2009; Kim and Shin 2013; Cheng 2014; Goniewicz et al. 2014b; Tayyarah and Long 2014; Farsalinos et al. 2015a; Flora et al. 2016). For example, Kim and Shin (2013) found an average of $12.99 \pm 18.23 \mu \mathrm{g} / \mathrm{L}$ of these toxicants in $105 \mathrm{EC}$ liquids from Korean shops. TSNAs are derived from tobacco leaves and are very potent carcinogens due to their ability to form DNA adducts, inhibiting tumour suppressor genes and activating oncogenes (Xue et al. 2014). Because ECs do not contain tobacco, they should not contain TSNAs, which indicates that their presence is the result of nicotine contaminants (Farsalinos et al. 2015a). However, EC TSNAs are mostly found in concentrations much lower than in CCs (Farsalinos et al. 2015a; Flora et al. 2016), and some studies did not detect them in EC liquids or vapours at all (Kavvalakis et al. 2015). Improving the regulation of the EC manufacturing process should reduce the number of contaminants as well as increase the agreement between the amount of nicotine claimed by the manufacturer and the actual amount, which would make these devices safer to use as smoking cessation devices. Finally, manufacturing could also be improved in terms of the design (e.g., limitation of the power output) and quality of EC devices. Poor workmanship in terms of the quality of the batteries and heating elements can increase the concentration of toxic metals found in aerosolant (Kong et al. 2016; Loewenstein and Middlekauff 2017). Overall, ECs deliver a wide array of aerosolants, ranging from some known irritants to carcinogens. To better understand the health implications of EC use, we need to review the literature on the health effects of these toxicants in cells and organisms at the concentrations found in the above studies.

\section{Cellular level effects}

Studies of the cellular level response to EC liquids and aerosols can be categorized as either in vitro or in vivo. Table 1 summarizes many representative recent studies. Results from Table 1 show that EC devices are capable of causing damage at a cellular level. EC vapours can directly cause respiratory cell death by inducing apoptosis or necrosis (Bahl et al. 2012; Romagna et al. 2013; Cervellati et al. 2014; Willershausen et al. 2014; Scheffler et al. 2015a, 2015b; Schweitzer et al. 2015; Tartell 2015). Hom et al. (2016) also reported platelet activation, aggregation, and adhesion under EC vapour extracts in vitro. However, some researchers report no cytotoxicity involved with ECs (Wu et al. 2014). For instance, cytological examination of the oral mucosa led Franco et al. (2016) to conclude that EC use is safe for oral cells. These varying results could be explained by different EC liquids being used between studies or different exposure techniques (e.g., varying puff regimes). For instance, inoculating cells by soaking them in liquid (e.g., Aug et al. 2015; Sancilio et al. 2016) versus exposing cells to smoke condensate (e.g., Yu et al. 2016) or vapours (e.g., Sussan et al. 2015) are likely to lead to different results. In addition, some studies took $3 \mathrm{~s}$ puffs on the devices 
Table 1. Effects of electronic cigarette liquids and vapours at the cellular level in vitro and in vivo.

\begin{tabular}{|c|c|c|c|c|c|}
\hline Reference & $\begin{array}{l}\text { Cell type(s) and } \\
\text { (or) organism type(s) }\end{array}$ & $\begin{array}{l}\text { In vitro and } \\
\text { (or) in vivo }\end{array}$ & Exposure & Methods & Results \\
\hline Bahl et al. (2012) & hESC, mNSC, hPF & In vitro & EC liquid over $48 \mathrm{~h}$ & $\begin{array}{l}\text { Test } 35 \text { EC liquids for toxicity } \\
\text { with MTT colorimetric assay }\end{array}$ & $\begin{array}{l}\text { Varying cytotoxicity among different brands/ } \\
\text { flavours though hESCs were almost always } \\
\text { more sensitive than mNSC or hPF. }\end{array}$ \\
\hline $\begin{array}{l}\text { Cervellati et al. } \\
\text { (2014) }\end{array}$ & A549, $\mathrm{HaCaT}$ & In vitro & $\begin{array}{l}50 \text { min exposure to } \mathrm{EC} \\
\text { vapour, sample } \\
\text { periodically over } 24 \mathrm{~h}\end{array}$ & $\begin{array}{l}\text { Vacuum pump for exposure, } \\
\text { trypan blue and LDH } \\
\text { assay for viability }\end{array}$ & $\begin{array}{l}\text { EC without flavour or nicotine: no effect. EC with } \\
\text { flavour and EC with nicotine decreased viability } \\
\text { and increased cell damage, similar to CCs. }\end{array}$ \\
\hline $\begin{array}{l}\text { Farsalinos et al. } \\
\text { (2013) }\end{array}$ & $\mathrm{H} 9 \mathrm{c} 2$ & In vitro & $\begin{array}{l}2.5 \text { and } 4 \mathrm{~s} \text { puffs of vapour } \\
\text { every } 60 \mathrm{~s} \text { for high and } \\
\text { regular voltage EC devices, } \\
\text { until consumption of } 200 \mathrm{mg} \\
\text { of EC liquid: } \mathrm{H} 9 \mathrm{c} 2 \text { cells } \\
\text { soaked in liquid for } 24 \mathrm{~h}\end{array}$ & $\begin{array}{l}\text { Test } 20 \text { EC liquids for } \\
\text { toxicity with MTT } \\
\text { colorimetric assay }\end{array}$ & $\begin{array}{l}\text { Varying cytotoxicity among different brands/ } \\
\text { flavours, more pronounced effects at higher } \\
\text { concentrations, cell survival was not associated } \\
\text { with nicotine concentration of EC liquids, } \\
\text { viability reduced for EC extracts produced by } \\
\text { high-voltage EC devices. }\end{array}$ \\
\hline $\begin{array}{l}\text { Garcia-Arcos et al. } \\
\text { (2016) }\end{array}$ & NHBE, live mice & $\begin{array}{l}\text { In vitro and } \\
\text { in vivo }\end{array}$ & $\begin{array}{l}\text { NHBE cells: puffs of } \\
\text { vapour every } 30 \mathrm{~s} \text { for } \\
\text { a total of } 36 \text { puffs } \\
\text { Mice: } 1 \mathrm{~h} \text { of aerosol } \\
\text { per day for four } \\
\text { months }\end{array}$ & $\begin{array}{l}\text { In vivo: Histological and } \\
\text { immuno-fluorescence } \\
\text { analysis of lung tissue, } \\
\text { TUNEL cell viability test, } \\
\text { qPCR for gene expression } \\
\text { In vitro: LDH release for } \\
\text { viability, histological } \\
\text { analysis }\end{array}$ & $\begin{array}{l}\text { In vivo: nicotine-containing EC vapour } \\
\text { increased cytokine and protease expression, } \\
\text { airway hyperreactivity, lung tissue destruction, } \\
\text { mucin production whereas nicotine-free EC } \\
\text { vapour did not. } \\
\text { In vitro: nicotine-containing EC vapour } \\
\text { impaired ciliary beat frequency, airway surface } \\
\text { liquid volume, cystic fibrosis transmembrane } \\
\text { regulator, and ATP-stimulated K+ ion } \\
\text { conductance of NHBE cells. }\end{array}$ \\
\hline $\begin{array}{l}\text { Higham et al. } \\
(2016)\end{array}$ & Human neutrophils & In vitro & $\begin{array}{l}10 \mathrm{~s} \text { puffs of vapour } \\
\text { every } 30 \mathrm{~s} \text { for a total } \\
\text { of } 13 \mathrm{~min}\end{array}$ & $\begin{array}{l}\text { Expression of CD11b and } \\
\text { CD66b measured by flow } \\
\text { cytometry, MMP-9 and } \\
\text { CXCL8 by ELISA }\end{array}$ & $\begin{array}{l}\text { Vapours increased expression of CD11b and } \\
\text { CD66b (markers of neutrophil activation) and } \\
\text { increased neutrophil elastase and MMP-9 } \\
\text { activity (both causing tissue destruction and } \\
\text { leading to emphysema). }\end{array}$ \\
\hline $\begin{array}{l}\text { Husari et al. } \\
(2016)\end{array}$ & A549, live mice & $\begin{array}{l}\text { In vitro and } \\
\text { in vivo }\end{array}$ & $\begin{array}{l}\text { A549 cells: EC condensate } \\
\text { added to culture media, } \\
\text { media tested at various } \\
\text { concentrations of } \\
\text { aerosol extracts } \\
\text { Mice: } 6 \text { h of aerosol } \\
\text { per day for } 3 \mathrm{~d}\end{array}$ & $\begin{array}{l}\text { In vitro: cell titer blue } \\
\text { assay for viability } \\
\text { In vivo: albumin level, } \\
\text { qPCR for inflammatory } \\
\text { mediators IL-1 } \beta \text {, IL- } 6 \text {, } \\
\text { TNF- } \alpha \text {, tested oxidative } \\
\text { stress and cell death }\end{array}$ & $\begin{array}{l}\text { No albumin leak, no cell death, and low levels of } \\
\text { lung damage found in ECs when compared with } \\
\text { CCs. Significant increase in IL- } 1 \beta \text { for ECs and in } \\
\text { all three mediators ( } 1 \beta \text {, IL- } 6 \text {, TNF- } \alpha \text { ) for CC use. }\end{array}$ \\
\hline
\end{tabular}




\begin{tabular}{|c|c|c|c|c|c|}
\hline Reference & $\begin{array}{l}\text { Cell type(s) and } \\
\text { (or) organism type(s) }\end{array}$ & $\begin{array}{l}\text { In vitro and } \\
\text { (or) in vivo }\end{array}$ & Exposure & Methods & Results \\
\hline Leigh et al. (2016) & $\mathrm{H} 292$ & In vitro & $\begin{array}{l}3 \mathrm{~s} \text { puffs of vapour every } \\
30 \mathrm{~s} \text { for a total of } 30 \mathrm{~min}\end{array}$ & $\begin{array}{l}\text { Neutral red test for metabolic } \\
\text { activity, trypan blue assay } \\
\text { for viability, measured } \\
\text { cytokine release with ELISA }\end{array}$ & $\begin{array}{l}\text { Vapours decreased metabolic activity and cell } \\
\text { viability and increased release of various } \\
\text { cytokines, CCs had more detrimental effects } \\
\text { on cell viability and metabolic activity, } \\
\text { metabolic activity and viability reduced further } \\
\text { for EC extracts produced by higher voltage EC } \\
\text { devices ( } 4 \text { and } 4.8 \mathrm{~V} \text { vs. } 3.3 \mathrm{~V}) \text {, cytotoxicity } \\
\text { varied depending on the type of flavour used. }\end{array}$ \\
\hline $\begin{array}{l}\text { Lerner et al. } \\
(2015 b)\end{array}$ & $\begin{array}{l}\text { H292, HFL-1, } \\
\text { live mice }\end{array}$ & $\begin{array}{l}\text { In vitro and } \\
\text { in vivo }\end{array}$ & $\begin{array}{l}\text { H292 cells: } 4 \mathrm{~s} \text { puffs of } \\
\text { vapour every } 30 \mathrm{~s} \text { for } \\
5,10 \text {, or } 15 \mathrm{~min} \\
\text { HFL- } 1 \text { cells: soaked in } \\
\text { liquid for } 24 \mathrm{~h} \\
\text { Mice: } 5 \text { h of aerosol } \\
\text { per day for } 3 \mathrm{~d}\end{array}$ & $\begin{array}{l}\text { In vitro: tested ROS } \\
\text { generation and IL-8 } \\
\text { release } \\
\text { In vivo: tested macrophage } \\
\text { and IL release }\end{array}$ & $\begin{array}{l}\text { In vitro: ROS generated by device, humectants, } \\
\text { and complete liquids, IL- } 8 \text { release correlated } \\
\text { with nicotine. } \\
\text { In vivo: vapours caused increased } \\
\text { macrophages and IL in lungs. }\end{array}$ \\
\hline $\begin{array}{l}\text { Lim and Kim } \\
(2014)\end{array}$ & Live mice & In vivo & $\begin{array}{l}\text { Inject EC liquid into } \\
\text { trachea twice weekly } \\
\text { for } 10 \text { weeks, tested } \\
24 \mathrm{~h} \text { after last dose }\end{array}$ & $\begin{array}{l}\text { Measure airway } \\
\text { inflammation and airway } \\
\text { hyperresponsiveness }\end{array}$ & $\begin{array}{l}\text { EC increased hyperresponsiveness and } \\
\text { attracted leukocytes and eosinophils } \\
\text { (indicating inflammation and allergies). }\end{array}$ \\
\hline $\begin{array}{l}\text { Misra et al. } \\
(2014)\end{array}$ & A549 & In vitro & $\begin{array}{l}2 \mathrm{~s} \text { puffs of vapour every } \\
30 \mathrm{~s} \text { or soaked in EC } \\
\text { liquid, tested } 24 \mathrm{~h} \text { after } \\
\text { exposure }\end{array}$ & $\begin{array}{l}\text { Neutral red test for } \\
\text { cytotoxicity, measured } \\
\text { cytokine release with ELISA, } \\
\text { Ames and micronucleus } \\
\text { assay for mutagenicity }\end{array}$ & $\begin{array}{l}\text { No effect besides IL- } 8 \text { release at very high dose } \\
\text { of EC liquid. }\end{array}$ \\
\hline $\begin{array}{l}\text { Neilson et al. } \\
(2015)\end{array}$ & $\begin{array}{l}\text { Human } \\
\text { tracheobronchial } \\
\text { epithelium: }^{\mathrm{TM}} \\
\text { EpiAirway }^{\mathrm{M}}\end{array}$ & In vitro & $\begin{array}{l}3 \mathrm{~s} \text { puffs of vapour every } \\
30 \mathrm{~s} \text { for a total of } 30 \mathrm{~min}\end{array}$ & $\begin{array}{l}\text { Test for toxicity with MTT } \\
\text { colorimetric assay }\end{array}$ & $\begin{array}{l}\text { No decreased cell viability with EC vapour, } \\
12 \% \text { decrease for CC smoke. }\end{array}$ \\
\hline \multirow[t]{2}{*}{$\begin{array}{l}\text { Palpant et al. } \\
\text { (2015) }\end{array}$} & $\begin{array}{l}\text { hESC, live zebrafish } \\
\text { embryos }\end{array}$ & $\begin{array}{l}\text { In vitro and } \\
\text { in vivo }\end{array}$ & $\begin{array}{l}\text { Vapour drawn over } \\
\text { culture media for cells } \\
\text { and embryos, tested } 24,48, \\
\text { and } 72 \mathrm{~h} \text { after exposure }\end{array}$ & $\begin{array}{l}\text { In vitro: tested gene } \\
\text { expression }\end{array}$ & $\begin{array}{l}\text { In vitro: vapours reduced expression of } \\
\text { sarcomeres. }\end{array}$ \\
\hline & & & & $\begin{array}{l}\text { In vivo: observed cardiac } \\
\text { development }\end{array}$ & $\begin{array}{l}\text { In vivo: vapours caused cardiac defects } \\
\text { (decreased contractile and junctional proteins) } \\
\text { unrelated to nicotine, no effect on heart beat. }\end{array}$ \\
\hline $\begin{array}{l}\text { Romagna et al. } \\
\text { (2013) }\end{array}$ & BALB/3T3 & In vitro & $\begin{array}{l}2 \mathrm{~s} \text { puffs every } 60 \mathrm{~s} \text {, tested } \\
24 \mathrm{~h} \text { after exposure }\end{array}$ & $\begin{array}{l}\text { MTT assay for viability } \\
\text { of } 21 \text { EC liquids at different } \\
\text { concentrations }\end{array}$ & $\begin{array}{l}\text { Only one "coffee" liquid was cytotoxic and } \\
\text { only at the highest concentration tested. }\end{array}$ \\
\hline
\end{tabular}




\begin{tabular}{|c|c|c|c|c|c|}
\hline Reference & $\begin{array}{l}\text { Cell type(s) and } \\
\text { (or) organism type(s) }\end{array}$ & $\begin{array}{l}\text { In vitro and } \\
\text { (or) in vivo }\end{array}$ & Exposure & Methods & Results \\
\hline $\begin{array}{l}\text { Scheffler et al. } \\
(2015 a)\end{array}$ & NHBE, A549 & In vitro & $\begin{array}{l}2 \mathrm{~s} \text { puffs every } 10 \mathrm{~s} \\
\text { tested } 24 \mathrm{~h} \text { after } \\
\text { exposure }\end{array}$ & $\begin{array}{l}\text { Cell titer blue assay for } \\
\text { viability, ROS-Glo } \mathrm{H}_{2} \mathrm{O}_{2} \\
\text { assay for oxidative stress }\end{array}$ & $\begin{array}{l}\text { Vapours decreased viability unrelated to } \\
\text { nicotine, bronchial cells more sensitive } \\
\text { than A549, bronchial cells showed oxidative } \\
\text { stress, not A549. }\end{array}$ \\
\hline $\begin{array}{l}\text { Scheffler et al. } \\
\text { (2015b) }\end{array}$ & NHBE & In vitro & $\begin{array}{l}2 \text { s puffs, } 200 \text { puffs, } \\
\text { tested } 24 \text { h after } \\
\text { exposure }\end{array}$ & $\begin{array}{l}\text { Cell titer blue assay for } \\
\text { viability, ROS-Glo } \mathrm{H}_{2} \mathrm{O}_{2} \\
\text { assay for oxidative stress }\end{array}$ & $\begin{array}{l}\text { EC vapour, propylene glycol, and glycerol } \\
\text { reduced viability and increased oxidative } \\
\text { stress unrelated to nicotine. }\end{array}$ \\
\hline \multirow[t]{2}{*}{$\begin{array}{l}\text { Schweitzer et al. } \\
(2015)\end{array}$} & $\begin{array}{l}\text { Rat lung epithelial } \\
\text { cells, NHBE, primary } \\
\text { mouse lung endothelial } \\
\text { cells, primary human } \\
\text { lung microvascular } \\
\text { cells, live mice }\end{array}$ & $\begin{array}{l}\text { In vitro and } \\
\text { in vivo }\end{array}$ & $\begin{array}{l}\text { In vitro: } 125 \mu \mathrm{L} \text { of EC } \\
\text { condensate added to } \\
\text { culture media }\end{array}$ & $\begin{array}{l}\text { MTT assay for viability, } \\
\text { tested oxidative stress, } \\
\text { tested protein expression }\end{array}$ & $\begin{array}{l}\text { In vitro: vapours caused decreased viability } \\
\text { and growth unrelated to nicotine and } \\
\text { increased oxidative stress (increased ROS). }\end{array}$ \\
\hline & & & $\begin{array}{l}\text { In vivo: } 2 \text { doses }(1 \mu \mathrm{g} \\
\text { each) of vapour, tested } \\
30 \text { min or } 24 \mathrm{~h} \text { after } \\
\text { exposure }\end{array}$ & & $\begin{array}{l}\text { In vivo: vapours caused oxidative stress } \\
\text { (increased in } 8-\mathrm{OHdG} \text { ) and increased } \\
\text { polymorphonuclear cells in lungs } \\
\text { (inflammation). }\end{array}$ \\
\hline $\begin{array}{l}\text { Sussan et al. } \\
(2015)\end{array}$ & Live mice & In vivo & $\begin{array}{l}2 \mathrm{~s} \text { puffs every } 10 \mathrm{~s} \text { for } 1.5 \mathrm{~h} \\
\text { twice a day for two weeks, } \\
\text { tested } 24 \mathrm{~h} \text { after exposure }\end{array}$ & $\begin{array}{l}\text { Measured IL levels, } \\
\text { susceptibility to } \\
\text { bacterial and viral } \\
\text { infections }\end{array}$ & $\begin{array}{l}\text { Vapours caused oxidative stress (but no IL } \\
\text { release), macrophage infiltration, increased } \\
\text { susceptibility to bacterial infections (and } \\
\text { macrophage phagocytosis was impaired), } \\
\text { and viral infections (more infected cells and } \\
\text { death than in the control). }\end{array}$ \\
\hline Tartell (2015) & A549 & In vitro & $\begin{array}{l}\text { Soaked in liquid for up } \\
\text { to } 120 \mathrm{~min}\end{array}$ & $\begin{array}{l}\text { LDH release for viability, } \\
\text { tested protein expression }\end{array}$ & $\begin{array}{l}\text { Liquid was cytotoxic above } 5 \% \text {, caused } \\
\text { release of NF Kappa genes which stimulate } \\
\text { inflammation. }\end{array}$ \\
\hline $\begin{array}{l}\text { Teasdale et al. } \\
\text { (2016) }\end{array}$ & HCAEC & In vitro & $\begin{array}{l}\text { EC condensate added to } \\
\text { culture media with a } \\
350 \mathrm{ng} / \mathrm{mL} \text { nicotine } \\
\text { concentration }\end{array}$ & $\begin{array}{l}\text { qPCR for expression of } \\
\text { regulatory genes, immuno- } \\
\text { chemistry to detect oxidant- } \\
\text { stress sensing transcription } \\
\text { factor NFR2 }\end{array}$ & $\begin{array}{l}\text { Oxidative stress pathway activated and } \\
\text { cytochrome p } 450 \text { upregulated for CC smoke } \\
\text { condensate, but not EC condensate. }\end{array}$ \\
\hline $\begin{array}{l}\text { Willershausen } \\
\text { et al. (2014) }\end{array}$ & $\begin{array}{l}\text { Human periodontal } \\
\text { ligament fibroblasts }\end{array}$ & In vitro & $\begin{array}{l}\text { Soaked in liquid for up } \\
\text { to } 96 \mathrm{~h}\end{array}$ & $\begin{array}{l}\text { Presto Blue cell proliferation } \\
\text { assay for viability, tested } \\
\text { cell migration }\end{array}$ & $\begin{array}{l}\text { Only menthol flavoured liquid decreased } \\
\text { viability (not hazelnut, lime, or pure } \\
\text { nicotine), only menthol reduced migration. }\end{array}$ \\
\hline Wu et al. (2014) & hTBE & In vitro & $\begin{array}{l}\text { Soaked in liquid for } \\
\text { up to } 48 \mathrm{~h}\end{array}$ & $\begin{array}{l}\text { LDH release for viability, } \\
\text { tested IL levels, tested } \\
\text { response to viral infection }\end{array}$ & $\begin{array}{l}\text { No cytotoxicity, liquids caused IL- } 6 \text { release, } \\
\text { more so when it contained nicotine, liquid } \\
\text { increased number of virally infected cells and } \\
\text { decreased SPLUNCI (virus defense molecule) } \\
\text { levels for nicotine and non-nicotine liquids. }\end{array}$ \\
\hline
\end{tabular}




\begin{tabular}{|c|c|c|c|c|c|}
\hline Reference & $\begin{array}{l}\text { Cell type(s) and } \\
\text { (or) organism type(s) }\end{array}$ & $\begin{array}{l}\text { In vitro and } \\
\text { (or) in vivo }\end{array}$ & Exposure & Methods & Results \\
\hline Yu et al. (2016) & HaCAT, hNSCC & In vitro & $\begin{array}{l}\text { Vapour absorbed by } \\
\text { media used to culture } \\
\text { cells, replaced every } 3 \mathrm{~d} \\
\text { for eight weeks (HaCaT) } \\
\text { or one week (hNSCC) }\end{array}$ & $\begin{array}{l}\text { Trypan blue assay for } \\
\text { viability, detected double- } \\
\text { stranded DNA breaks by } \\
\text { detecting } \gamma-\mathrm{H} 2 \mathrm{AX} \text {, detected } \\
\text { cells undergoing apoptosis }\end{array}$ & $\begin{array}{l}\text { HaCat: } 1.5 \text { and } 3 \text { times more double-strand } \\
\text { breaks for non-nicotine and nicotine vapour, } \\
\text { respectively, } 0.53 \text { to } 0.68 \text { times more necrosis, } \\
1.2 \text { to } 2 \text { times more apoptosis than in the } \\
\text { control. } \\
\text { hNSCC: } 1.5 \text { and } 2 \text { times more double-strand } \\
\text { breaks for non-nicotine and nicotine vapour, } \\
\text { respectively, } 0.2 \text { to } 1.34 \text { times more necrosis, } \\
1.21 \text { to } 2.58 \text { times more apoptosis than in the } \\
\text { control. } \\
\text { Both cells: } 5 \text { and } 10 \text { times more cell death for } \\
\text { non-nicotine and nicotine vapours, respectively. }\end{array}$ \\
\hline
\end{tabular}

Note: EC, electronic cigarette; hESC, human embryonic stem cells; mNSC, mouse neural stem cells; hPF, human pulmonary fibroblasts; A549, human lung epithelial cells; HaCaT, human keratinocytes; H9c2, human cardiomyocytes; NHBE, human bronchial epithelial cells; H292, human bronchial epithelial cells; HFL-1, human fetal lung fibroblasts; BALB/3T3, mouse embryo fibroblasts; HCAEC, human coronary artery endothelial cells; hTBE, human tracheobronchial epithelial cells; HaCAT, human keratinocytes; hNSCC, head and neck squamous cell carcinoma; ROS, reactive oxygen species; CC, conventional cigarette. 
with $30 \mathrm{~s}$ intervals, some did $2 \mathrm{~s}$ puffs with $60 \mathrm{~s}$ intervals, some just used a continuous stream of vapour, and the number of exposures was often different. Table 1 illustrates this high diversity of methodologies and exposure times, making broad generalizations on cytotoxicity difficult. ECs can cause inflammation, which could potentially cause or aggravate conditions like chronic obstructive pulmonary disease (COPD), by inducing the release of interleukins, which are inflammatory mediators, attracting macrophages to the area, and causing oxidative damage via ROS (Lim and Kim 2014; Misra et al. 2014; Wu et al. 2014; Lerner et al. 2015a; Schweitzer et al. 2015; Sussan et al. 2015; Tartell 2015; Anderson et al. 2016; Garcia-Arcos et al. 2016; Ji et al. 2016; Shivalingappa et al. 2016). In addition, ECs are capable of reducing the ability of a person's immune system to fight off both bacterial and viral infections (Sussan et al. 2015; Hwang et al. 2016). This could be attributed to a decreased ability of pulmonary macrophages to phagocytize, as well as fewer viral defense molecules like SPLUNCI in the lungs (Wu et al. 2014; Sussan et al. 2015). In addition, exposure to the vapours from ECs can cause DNA damage in cells (Anderson et al. 2016; Yu et al. 2016). DNA breaks could be caused by the known carcinogens that exist in EC vapours, like formaldehyde, as discussed previously. EC vapours can also induce gene expression changes in vivo in nasal epithelium (Martin et al. 2016) or in vitro in bronchial airway epithelium (Moses et al. 2017), or in acetylcholine receptors associated with tumour progression (Schaal and Chellappan 2016). It should be noted that many of the above results were not related to the nicotine that is sometimes present in the vapours but to the humectants like propylene glycol, glycerol, and any flavouring compounds that may exist in the solution (though nicotine sometimes enhanced the damaging effects). Long-term studies of the effects of EC use such as effects on tumour promotion and progression, or overall cytological function are rare and clearly needed.

From the 22 studies cited in Table 1, 12 compared the cellular level effects of ECs with the effects of CCs. Although ECs can cause harmful effects in cells, they are usually at a much lower magnitude than the harmful effects of CCs (11 out of 12 studies: Farsalinos et al. 2013; Romagna et al. 2013; Cervellati et al. 2014; Misra et al. 2014; Neilson et al. 2015; Palpant et al. 2015; Scheffler et al. 2015a, 2015b; Husari et al. 2016; Leigh et al. 2016; Teasdale et al. 2016). For instance, Misra et al. (2014) found no cytotoxicity or mutagenicity of EC aerosols, but found high cytotoxicity and mutagenicity of CC smoke in human lung epithelial cells (A549). Also, Scheffler et al. (2015b) discovered reduced viability and increased oxidative stress when human bronchial epithelial (NHBE) cells were exposed to EC humectants, but much lower viability and higher oxidative stress when the same cells were exposed to CC smoke (see also Taylor et al. 2016 for similar results). Carnevale et al. (2016) found similar results in healthy subjects with increased oxidative stress while vaping. In one study mentioned in Table 1 (Higham et al. 2016), vapours from ECs caused a pro-inflammatory response from human neutrophils. In that study, the effects were similar or more pronounced with EC vapours than with CC smoke extracts. Interpreting these results is difficult as sample sizes tend to be low, methodologies vary, and acute effects and in vitro studies do not necessarily translate well to overall long-term health effects. In addition, some measured biomarkers may not necessarily represent good predictors of disease risk. For instance, acute exposure to caffeine can have similar effects on aspects of oxidative stress response or endothelial cell function in the cardiovascular system as those found for EC aerosols (Buscemi et al. 2010; Martini et al. 2016). Therefore, some biomarkers such as intracellular ROS may not be the best estimators of potential EC vapour toxicity for users (Putzhammer et al. 2016). Taken together, results suggest that, while the effects of ECs on health are not negligible, they are generally lower in magnitude than for CCs. However, given the diversity of products available on the market, it is not surprising to find some products to be as cytotoxic as CCs, whereas others are much less toxic (Putzhammer et al. 2016).

\section{Overall physiological effects}

The literature that focuses on overall physiological effects of ECs can be divided into a few subtopics of importance. In this review, we focus on the delivery of nicotine into the blood, the effects on 
cardiovascular function, the effects on pulmonary function, the effects on metabolism and development, the effects on cognitive function, and the acute adverse effects of smoking. In this section, we lump studies conducted on humans and animal models together.

\section{Delivery of nicotine to the blood by EC devices}

When smoking a CC, users tend to take quick, deep inhalations, which produce more smoke. Experienced vapers tend to take longer, slower inhalations, which produce more aerosols from an EC (Farsalinos et al. 2015c). Thus, experienced vapers are exposed to higher levels of the chemicals that exist in EC vapour (including nicotine) than an EC user who is trying the device for the first time (Hajek et al. 2015). Lee et al. (2015) provided current smokers with nicotine ECs and allowed them to use the devices ad libitum for two weeks. Over this time period, the number of puffs, puff intervals, and puff volume did not change, but after just $7 \mathrm{~d}$ of EC use, the smokers increased their puff duration from $2.2 \pm 0.1 \mathrm{~s}$ to $3.1 \pm 0.3 \mathrm{~s}$ and their puff flow rate from $30.6 \pm 2.3 \mathrm{~mL} / \mathrm{s}$ to $25.1 \pm 1.8 \mathrm{~mL} / \mathrm{s}$ to produce the desired amount of blood nicotine (Lee et al. 2015). In another study, vapers engaged in compensatory puffing by increasing the number of puffs and their duration in a low nicotine e-liquid strength condition when compared with a higher strength condition (Dawkins et al. 2016). Blood nicotine concentrations tend to peak much faster when smoking a CC than when using an EC, indicating differing nicotine absorption and reduction of cigarette cravings (D'Ruiz et al. 2015). Besides device familiarity, another important factor is the type of EC device that is being used in the study. The original ECs, called "first-generation" devices, were designed to look like a CC and were relatively low power (Farsalinos et al. 2014b). There are different ECs that have come out in recent years, called "new generation" devices. These devices can look like common household items such as pens or have a completely unique design and have a much higher voltage and (or) resistance and, therefore, power than the first-generation devices (Farsalinos et al. 2014b). This higher power allows the user to generate more aerosols per puff than the first-generation devices, again exposing users to more of the vapour chemicals like nicotine (Wagener et al. 2017). These factors (experience of the subjects, individual habits, and type of device and liquid) can explain some of the discrepancies in the literature and can cause different blood nicotine levels even if the exact same product is in use (Dawkins and Corcoran 2014). Gallart-Mateu et al. (2016) discovered that nicotine levels in saliva of passive vapers were lower than nicotine levels of CC users. In a separate study, these effects were reflected in lower urinary nicotine levels with EC use than with CC use (Hecht et al. 2015; but see Göney et al. 2016). Similarly, Bullen et al. (2010) and Vélez de Mendizábal et al. (2015) discovered that ECs produce lower blood nicotine concentrations than CCs. These results must be interpreted with caution as these studies were mostly performed with subjects who were inexperienced with ECs. Pacifici et al. (2015) found that ECs could generate comparable levels of nicotine to CCs in smokers that were instructed by medical professionals on how to use the device. Vansickel and Eissenberg (2013) found that experienced vapers allowed to use their own device ad libitum for $1 \mathrm{~h}$ were able to generate blood nicotine concentrations of $16.3 \pm 4.5 \mathrm{ng} / \mathrm{mL}$, similar to CC use. Similarly, in two separate studies, EC users allowed to use an EC device for 15 puffs also produced levels of blood nicotine (and systemic retention times) comparable with or higher than CCs (El-Hellani et al. 2016; St. Helen et al. 2016). Specifically, when loaded with EC liquid containing $36 \mathrm{mg} / \mathrm{mL}$ of nicotine, users can generate blood nicotine concentrations of $30.2 \pm 5 \mathrm{ng} / \mathrm{mL}$, exceeding CC nicotine levels (Ramôa et al. 2016). These results are similar when analyzing saliva rather than blood, as experienced vapers can generate salivary nicotine derivative levels similar to smokers, as determined by analyzing samples solicited over the internet (Etter 2014). This may be due to changing puffing topography or to the fact that nicotyrine, a compound that exists with nicotine, builds up over time in the liquids. Nicotyrine inhibits the breakdown of nicotine in the liver and, therefore, increases nicotine concentration in the blood (Abramovitz et al. 2015). This may account for EC users becoming more satisfied with their nicotine-containing devices after a few days of use (McQueen et al. 2011). 
Reported secondhand effects are scarce and include mostly minor acute effects such as coughing (Durmowicz et al. 2016; see respective section on acute effects below). However, salivary nicotine derivatives were elevated in non-users who lived in the home of someone who vaped indoors (Ballbè et al. 2014). These levels were similar to those of people who lived with indoor CC smokers (Ballbè et al. 2014). The thirdhand nicotine (in other words, exposure to nicotine from surface deposits) from ECs was negligible, especially compared with CCs (Bush and Goniewicz 2015). Therefore, both in terms of vaping or secondhand vaping, nicotine levels can be high (especially with newer devices) and similar to CCs (Goniewicz et al. 2017). If so, we should expect to see consequences of EC use on important body functions such as the cardiovascular or pulmonary systems.

\section{Effects of ECs on cardiovascular function}

Smoking CCs is known to have adverse effects on human cardiovascular function, such as increased heart rate, increased blood pressure, arterial stiffness, and increased risk of heart attack or stroke (e.g., Ambrose and Barua 2004). Therefore, it should not be surprising to find some of these detrimental effects on cardiovascular function with EC use. Vlachopoulos et al. (2016) reported increased aortic stiffness and increased blood pressure with a continuous 30 min vaping regime. In healthy volunteers, 10 puffs of EC aerosol for 10 min resulted in increased endothelial progenitor cells in blood at similar levels than after smoking one CC (Antoniewicz et al. 2016). Nides et al. (2014) found that use of an EC by 25 smokers educated and practiced in the use of the devices, over a period of $10 \mathrm{~min}$, increased heart rate from the base line by 2.4 beats $/ \mathrm{min}$ in the first $5 \mathrm{~min}$ and 10.3 beats $/$ min immediately after the $10 \mathrm{~min}$ period. Similarly, in two studies, heart rate increased by an average of 8 beats $/ \mathrm{min}$ (St. Helen et al. 2016) and 4.8 beats/min (Vansickel and Eissenberg 2013) after 5 min of nicotinecontaining EC use. Cooke et al. (2015b) showed that inhaled vapourized nicotine from ECs increased arterial pressure. Yan and D'Ruiz (2015) found that $1 \mathrm{~h}$ ad libitum use of nicotine-containing ECs by 26 smokers increased heart rate, systolic blood pressure, and diastolic blood pressure, though less than CCs for all factors but the diastolic blood pressure. D'Ruiz et al. (2015) found that when 24 smokers took $5 \mathrm{~s}$ puffs on nicotine-containing ECs with $30 \mathrm{~s}$ intervals for a total of $24.5 \mathrm{~min}$, their heart rate, systolic blood pressure, and diastolic blood pressure increased, though not as much as when CCs were similarly used. Finally, in a few pilot studies, subjects had reduced cutaneous blood flow (Page et al. 2016) and increased flow in the buccal mucosa (Reuther et al. 2016) following EC use. Although these effects may be transient, continual EC use and, therefore, repeated situations with raised heart rate and blood pressure could cause stress on the cardiovascular system, potentially leading to increased risk of heart attack or stroke, like with CCs. In contrast, some studies found no effects of EC use when compared with CCs. In a study of 76 people, 40 EC users and 36 CC smokers used nicotine-containing ECs or CCs for 7 min each (Farsalinos et al. 2014c). The use of CCs increased heart rate and isovolumetric relaxation, indicating diastolic dysfunction (Farsalinos et al. 2014c). In addition, CC use decreased mitral annulus diastolic velocity, indicating heart valve closing issues, decreased diastolic longitudinal deformation, and increased blood flow, all indicating myocardial pathology (Farsalinos et al. 2014c). However, the use of the ECs had no effect on cardiac function (Farsalinos et al. 2014c). Flouris et al. (2012) reported no changes in complete blood count indices an hour after EC use, whereas white blood cell, lymphocyte, and granulocyte count went up for CC users over the same time frame. Chronic idiopathic neutrophilia was reversed and white blood cell count improved in one patient when switching from CCs to ECs (Farsalinos and Romagna 2013). Szołtysek-Bołdys et al. (2014) found that the acute use of ECs did not have an effect on arterial stiffness, but the acute use of CCs did. Similarly, Walele et al. (2016) found that there was no change in cardiac function, including heart rate and blood pressure, after smokers took 10 puffs from nicotine and nicotine-free ECs four times per day for $4 \mathrm{~d}$. Finally, Farsalinos et al. (2016a) found a beneficial effect on systolic blood pressure of switching to ECs from CCs after following 145 participants for a year. Results from these above studies should be interpreted with caution. For instance, the 10 puffs or the 7 min exposure 
followed by an immediate electrocardiogram might not have been enough time for the nicotine to reach the blood through EC use because it is absorbed more slowly than with CC use, as discussed previously. In addition, it is possible that these smokers were inexperienced with the use of the device and, therefore, could not generate enough aerosols (and nicotine) to experience a change in cardiac function. In contrast, 30 min continuous vaping or high e-liquid concentrations may not necessarily represent realistic conditions for extrapolation when positive results are found. These differences in vaping duration and user experience are likely to explain why in some studies arterial stiffness increased with EC use, whereas it did not in others. Because most of these studies involved nicotine-containing ECs, it is difficult to say whether or not the perceived cardiac effects of ECs are due to nicotine solely. For instance, carbonyls found in EC vapour can cause significant cardiovascular toxicity (Bhatnagar 2016). Further clinical studies are required to understand fully the various effects of EC use. As with studies at the cellular level, results thus far suggest that EC use causes fewer acute effects than CCs. These effects are also lower in magnitude. In addition, EC aerosol does not contain many of the toxicants found in CC smoke that influence cardiovascular function (Benowitz and Burbank 2016; Margham et al. 2016). As such, for short-term use, ECs likely represent a safer alternative to smoking CCs when it comes to cardiovascular health. Future research should be done long term using a consistent smoking regime involving experienced vapers so that results may be better compared across studies and varying nicotine levels.

\section{Effects of ECs on pulmonary function}

As smokers are known to have impaired pulmonary function (e.g., Musk and de Klerk 2003), it is important to establish how ECs, if they are to replace CCs, affect pulmonary function. Ferrari et al. (2015) discovered that in a group of 10 smokers and 10 non-smokers, $5 \mathrm{~min}$ of ad libitum use of a nicotine-free EC decreased the FEV1 value and the forced expiratory flow after 25\% of the air in the lungs has been expelled (FEF25 value). This indicates that ECs can impair lung volume as well as the force lungs can generate, unrelated to nicotine. These effects were, however, more pronounced in the 10 smokers. Among the smokers, there was also a decreased peak (highest) expiratory flow (PEF value) when air was being expelled from the lungs (Ferrari et al. 2015). Walele et al. (2016) found no change in pulmonary function (including in values such as the FEV1) for flavoured or unflavoured liquid or varying nicotine concentrations when 24 smokers took 10 puffs from the EC device four times per day for $4 \mathrm{~d}$. Again, these different results may be due to different puffing regimes or the use of different liquids or devices that may affect lung function differently. One clinical study of 18 smoking asthmatics showed an improvement in their symptoms when they switched from CCs to ECs for a year, including a decrease in their airway hyperresponsiveness and an increase in their lung capacity (Polosa et al. 2014, 2016). This improvement might be explained by a reduced exposure to the excessive irritants and tar of CC smoke. Farsalinos et al. (2014a) received information from more than 19000 subjects through an internet survey where $65.4 \%$ of respondents with asthma and $75.7 \%$ of people with COPD said switching from CCs to ECs improved their symptoms. There is, therefore, some evidence that a switch from CCs to EC may provide some health benefits to users (Van Staden et al. 2013; Nutt et al. 2014; McRobbie et al. 2015; Polosa 2015; Campagna et al. 2016; Cibella et al. 2016; Goniewicz et al. 2017). Interestingly, recent studies suggest that the use of ECs lowers levels of expired nitric oxide (NO) (Vardavas et al. 2012; Marini et al. 2014; but see Flouris et al. 2013). As asthma patients generally tend to have elevated NO levels (Vahlkvist et al. 2006), the reported improvement of asthma symptoms with EC use may be related to NO. This early evidence does not, however, mean that EC use is harmless, only that it is safer than CCs (Flouris et al. 2013; Misra et al. 2014; Scheffler et al. 2015b; O'Connell et al. 2016). Future research should, therefore, look at these pulmonary results in more detail, especially in the long term (e.g., Polosa et al. 2016), and increase the scope to other organ systems. 


\section{Effects of ECs on metabolism and development}

Rats exposed to injections of nicotine-containing and nicotine-free EC liquid experienced changes in metabolism. In this study, total cholesterol (TC)/high density lipoproteins (HDL) and low density lipoproteins (LDL)/HDL levels went down (i.e., "bad" cholesterol) (El Golli et al. 2016b). However, these rats also had hyperglycemia and an increase in transaminase activity indicating liver damage, regardless of the nicotine level (El Golli et al. 2016b). Exposure of young mice to EC vapour resulted in less weight gain than a control, unrelated to nicotine, and less postnatal lung growth related to nicotine (McGrath-Morrow et al. 2015). Caenorhabditis elegans exposed to EC liquids or vapours resulted in smaller worms and smaller brood sizes than the controls, unrelated to nicotine, and decreased body length and locomotion related to nicotine content (Panitz et al. 2015). Thus, ECs can affect the development and metabolism of non-human animals, and these effects are exacerbated by nicotine. There are currently few studies that have examined the metabolic effects of EC use on humans. Recent studies suggest that switching to ECs may help in minimizing post-cessation weight gain experienced by four out of five smokers when quitting CC use (Russo et al. 2016). Nicotine exposure during pregnancy, adolescence, or adulthood can affect development and overall growth (Pauly and Slotkin 2008; Yuan et al. 2015). Future studies should focus on the acute and long-term effects of nicotine-containing ECs on these functions. This research is especially important if users, such as adolescents, use ECs as a new means of smoking rather than as a cessation device (Barrington-Trimis et al. 2016a, 2016b; Breland et al. 2016). Evidence to date, however, suggests this in not the case as the overwhelming majority of EC users are also smokers (Farsalinos et al. 2014a, 2016b; Patel et al. 2016; Hammett et al. 2017).

\section{Effects of ECs on cognitive function, anxiety, and dependence}

Nicotine exposure can impair cognitive abilities (Pauly and Slotkin 2008; Yuan et al. 2015). The few studies to date conducted with nicotine-containing ECs suggest similar results. Exposure to nicotine-containing EC vapours during late prenatal and early postnatal life of mice led to behavioural changes in adult male mice (Smith et al. 2015). Similarly, after being exposed to nicotine-containing EC aerosols (Ponzoni et al. 2015) or to e-liquid injections (El Golli et al. 2016a), the spatial memory of mice decreased. In addition, the amount of anxiety that the mice experienced increased (Ponzoni et al. 2015). These results were, however, more pronounced when mice were exposed to cigarette smoke (Ponzoni et al. 2015). These impairments are similar to those experienced by smokers as nicotine can cross the blood-brain barrier (Swan and Lessov-Schlaggar 2007). Nicotine withdrawal could also explain the anxiety experienced by the mice as it is a common symptom when smokers must go without CCs for a period of time (Jackson et al. 2015). In a recent study, long-term EC users and users vaping with recent devices or with higher nicotine concentrations reported high dependency scores (Foulds et al. 2015). This dependency was, however, lower than with CCs (Foulds et al. 2015). Other recent studies also reported dependency on EC liquids containing nicotine (Etter 2015; Etter and Eissenberg 2015), albeit lower than with CCs (Vansickel et al. 2012; Grace et al. 2015). Interestingly, mice that were exposed to EC vapour showed more anxiety-related compulsive behaviour than did those exposed to cigarette smoke, despite the similar blood nicotine levels and, therefore, similar withdrawal (Ponzoni et al. 2015). Lauterstein et al. (2016) found that mice pups exposed to EC vapours during gestation and early life had altered central nervous system development, regardless of whether e-liquid contained nicotine or not. These above-mentioned studies suggest that some non-nicotine component of ECs may affect normal behavioural and central nervous system development. Research on these potentially important non-nicotine effects is currently scarce. Furthermore, experienced users can generate high blood nicotine concentrations with new generation devices and certain types of e-liquids (see above). Thus, further research on humans is also required to understand better nicotine effects on cognitive function, anxiety, and nicotine dependence. 


\section{Acute adverse effects caused by EC use}

The most common acute adverse effects due to EC use were irritation of the respiratory tract (including the mouth and throat), dry throat, cough, and cough reflex suppression (Nides et al. 2014; D'Ruiz et al. 2015; Salturk et al. 2015; Dicpinigaitis et al. 2016a; Walele et al. 2016). These effects are probably due to the propylene glycol discussed earlier, which is a component of the EC liquid and is a known respiratory irritant. In addition, use of ECs lowers levels of expired NO, which may also contribute to irritation (Ricciardolo 2003; Vardavas et al. 2012; Marini et al. 2014). This irritation of the throat may be related to what is known as the "throat hit", a desirable sensation reported in an online 2015 survey of over 1000 users (Yingst et al. 2015; Etter 2016). A stronger "throat hit" tends to occur with increased nicotine, so in seeking a stronger "hit", people may be exposing themselves to more dangerous levels of nicotine and other toxicants (Etter 2016). Dicpinigaitis et al. (2016b) also found that, like CCs, the use of nicotine-containing ECs diminished the urge-to-cough sensation for $24 \mathrm{~h}$ after use when the users were exposed to capsaicin. This indicates some sort of reflex impairment with acute EC use. As mentioned earlier in this review, research on the acute effects of EC use is quickly adding up in the literature, whereas research on long-term effects of EC use is only in its infancy. Very few published studies focus on effects over months or years rather than hours (e.g., Manzoli et al. 2015, 2017; Cibella et al. 2016; Farsalinos et al. 2016a). This research will take time. It is, however, especially important to determine if toxicants found in ECs, but not in CCs, may pose serious health risks. For instance, patients with existing ulcerative colitis experience improvement of condition when smoking CCs (Calkins 1989), whereas symptoms worsen with EC use (Camus et al. 2014). Clearly, more research is needed before we can conclude on the overall long-term safety of EC use.

\section{Conclusions}

ECs are becoming an increasingly popular alternative to smoking CCs, which are perceived as more toxic. Some recent research even suggests some beneficial effects of switching from CCs to EC products, like for asthma patients. However, it is clear that EC use is not without associated risks. Acute use of these devices has been shown to lead to lung inflammation, which could cause or progress conditions such as COPD, oxidative damage, potential cardiac and pulmonary function impairment, potential behavioural modification, immunological effects, and more. Research is still very recent, and the exposure time in the majority of the papers is short (a few days), as researchers tend to focus on the acute effects of EC use. Therefore, we need to interpret current research with care as we still poorly understand how such acute effects translate to disease risk. Users should, therefore, use these devices with caution, especially given the lack of long-term studies of the health effects of EC use. However, evidence to date suggests that, when used properly, these devices can represent an effective replacement for CC use, at least in the short term, given the various health risks associated with CC smoke.

Broad conclusions and generalizations are difficult to make given that the sample sizes and methodologies for exposure to EC compounds vary wildly from paper to paper. For instance, many investigators looked at the effects of EC liquids on cells in vitro. It is difficult to extrapolate such findings to organ systems and organisms. Research that focuses on the effects of EC aerosolants may prove more practical. Other factors also vary among studies. Parameters such as exposure time, puffing rates, experience level of the user, type of device and its voltage and resistance, type of liquid used with various propylene glycol/glycerol ratio, nicotine, and flavouring compounds concentrations can vary among papers. These differences could potentially explain the varying levels of the same chemical in the aerosol or a different degree of cardiac function impairment. To draw meaningful broad conclusions, there is, therefore, a need for better standardization of protocols (e.g., Azzopardi et al. 2016; Farsalinos et al. 2016c; Iskandar et al. 2016). In addition, future researchers need to take advantage of other tools and methodologies such as randomized controlled trials (Cravo et al. 2016), and develop mathematical models and new frameworks (Kalkhoran and Glantz 2015; Levy et al. 2017). 
Finally, ECs also introduce a new suite of toxicants not found in CCs. Future research should focus on these new compounds introduced either by the devices themselves (e.g., metals such as nickel) or by the plethora of available unflavoured and flavoured liquids (e.g., glyoxals). The quantity or quality of the aerosolants produced by these products is still poorly regulated, and manufacturing processes need to be standardized.

\section{Acknowledgements}

AZ was supported by a research grant from the biology department at the University of the Fraser Valley. GS was supported by a sabbatical research leave grant from the University of the Fraser Valley. The authors would like to thank Nathan Bialas (UFV), two anonymous reviewers, and the subject editor for their review of the manuscript.

\section{Author contributions}

Conceived and designed the study: AZ. Performed the experiments/collected the data: AZ, GS. Analyzed and interpreted the data: AZ, GS. Contributed resources: AZ, GS. Drafted or revised the manuscript: GS.

\section{Competing interests}

The authors have declared that no competing interests exist.

\section{Data accessibility statement}

All relevant data are within the paper.

\section{References}

Abramovitz A, McQueen A, Martinez RE, Williams BJ, and Sumner W. 2015. Electronic cigarettes: the nicotyrine hypothesis. Medical Hypotheses, 85: 305-310. PMID:26100465. doi:10.1016/j. mehy.2015.06.002.

Allen JG, Flanigan SS, LeBlanc M, Vallarino J, MacNaughton P, Stewart JH, et al. 2016. Response to "Comment on 'Flavoring chemicals in e-cigarettes: diacetyl, 2,3-pentanedione, and acetoin in a sample of 51 products, including fruit-, candy-, and cocktail-flavored e-cigarettes"'. Environmental Health Perspectives, 124: 733-739. PMID:27248154. doi:10.1289/EHP348.

Ambrose JA, and Barua RS. 2004. The pathophysiology of cigarette smoking and cardiovascular disease: an update. Journal of the American College of Cardiology, 43: 1731-1737. PMID:15145091. doi:10.1016/j.jacc.2003.12.047.

Anderson C, Majeste A, Hanus J, and Wang S. 2016. E-cigarette aerosol exposure induces reactive oxygen species, DNA damage, and cell death in vascular endothelial cells. Toxicological Sciences, 154: 332-340. PMID:27613717. doi:10.1093/toxsci/kfw166.

Antoniewicz L, Bosson JA, Kuhl J, Abdel-Halim SM, Kiessling A, Mobarrez F, et al. 2016. Electronic cigarettes increase endothelial progenitor cells in the blood of healthy volunteers. Atherosclerosis, 255: 179-185. PMID:27693003. doi:10.1016/j.atherosclerosis.2016.09.064.

Aoshiba K, Nagai A, Yasui S, and Konno K. 1996. Nicotine prolongs neutrophil survival by suppressing apoptosis. Translational Research: The Journal of Laboratory and Clinical Medicine, 127: 186-194. PMID:8636647. doi:10.1016/S0022-2143(96)90077-3. 
Aug A, Altraja S, Kilk K, Porosk R, Soomets U, and Altraja A. 2015. E-cigarette affects the metabolome of primary normal human bronchial epithelial cells. PLoS ONE, 10: e0142053. PMID:26536230. doi:10.1371/journal.pone.0142053.

Azzopardi D, Patel K, Jaunky T, Santopietro S, Camacho OM, McAughey J, et al. 2016. Electronic cigarette aerosol induces significantly less cytotoxicity than tobacco smoke. Toxicology Mechanisms and Methods, 26: 477-491. PMID:27690199. doi:10.1080/15376516.2016.1217112.

Bahl V, Lin S, Xu N, Davis B, Wang Y-H, and Talbot P. 2012. Comparison of electronic cigarette refill fluid cytotoxicity using embryonic and adult models. Reproductive Toxicology, 34: 529-537. PMID:22989551. doi:10.1016/j.reprotox.2012.08.001.

Ballbè M, Martínez-Sánchez JM, Sureda X, Fu M, Pérez-Ortuño R, Pascual JA, et al. 2014. Cigarettes vs. e-cigarettes: passive exposure at home measured by means of airborne marker and biomarkers. Environmental Research, 135: 76-80. PMID:25262078. doi:10.1016/j.envres.2014.09.005.

Barrington-Trimis JL, Berhane K, Unger JB, Cruz TB, Urman R, Chou CP, et al. 2016a. The e-cigarette social environment, e-cigarette use, and susceptibility to cigarette smoking. Journal of Adolescent Health, 59: 75-80. PMID:27161417. doi:10.1016/j.jadohealth.2016.03.019.

Barrington-Trimis JL, Urman R, Berhane K, Unger JB, Cruz TB, Pentz MA, et al. 2016b. E-cigarettes and future cigarette use. Pediatrics, 138: e20160379. PMID:27296866. doi:10.1542/peds.2016-0379.

Behar RZ, Davis B, Wang Y, Bahl V, Lin S, and Talbot P. 2014. Identification of toxicants in cinnamonflavored electronic cigarette refill fluids. Toxicology In Vitro, 28: 198-208. PMID:24513812. doi:10.1016/j.tiv.2013.10.006.

Benowitz NL, and Burbank AD. 2016. Cardiovascular toxicity of nicotine: implications for electronic cigarette use. Trends in Cardiovascular Medicine, 26: 515-523. PMID:27079891. doi:10.1016/j. tcm.2016.03.001.

Bhatnagar A. 2016. E-cigarettes and cardiovascular disease risk: evaluation of evidence, policy implications, and recommendations. Current Cardiovascular Risk Reports, 10: 24. doi:10.1007/ s12170-016-0505-6.

Blair SL, Epstein SA, Nizkorodov SA, and Staimer N. 2015. A real-time fast-flow tube study of VOC and particulate emissions from electronic, potentially reduced-harm, conventional, and reference cigarettes. Aerosol Science and Technology, 49: 816-827. PMID:26726281. doi:10.1080/ 02786826.2015 .1076156$.

Breland A, Spindle T, Weaver M, and Eissenberg T. 2014. Science and electronic cigarettes: current data, future needs. Journal of Addiction Medicine, 8: 223-233. PMID:25089952. doi:10.1097/ ADM.0000000000000049.

Breland A, Soule E, Lopez A, Ramôa C, El-Hellani A, and Eissenberg T. 2016. Electronic cigarettes: what are they and what do they do? Annals of the New York Academy of Sciences, 1394: 5-30. PMID:26774031. doi:10.1111/nyas.12977.

Brown CJ, and Cheng JM. 2014. Electronic cigarettes: product characterisation and design considerations. Tobacco Control, 23: ii4-ii10. PMID:24732162. doi:10.1136/tobaccocontrol-2013-051476.

Bullen C, McRobbie H, Thornley S, Glover M, Lin R, and Laugesen M. 2010. Effect of an electronic nicotine delivery device (e cigarette) on desire to smoke and withdrawal, user preferences and nicotine 
delivery: randomised cross-over trial. Tobacco Control, 19: 98-103. PMID:20378585. doi:10.1136/ tc.2009.031567.

Buscemi S, Verga S, Batsis JA, Donatelli M, Tranchina MR, Belmonte S, et al. 2010. Acute effects of coffee on endothelial function in healthy subjects. European Journal of Clinical Nutrition, 64: 483489. PMID:20125186. doi:10.1038/ejcn.2010.9.

Bush D, and Goniewicz ML. 2015. A pilot study on nicotine residues in houses of electronic cigarette users, tobacco smokers, and non-users of nicotine-containing products. International Journal of Drug Policy, 26: 609-611. PMID:25869751. doi:10.1016/j.drugpo.2015.03.003.

Calkins BM. 1989. A meta-analysis of the role of smoking in inflammatory bowel disease. Digestive Diseases and Sciences, 34: 1841-1854. doi:10.1007/BF01536701.

Campagna D, Cibella F, Caponnetto P, Amaradio MD, Caruso M, Morjaria JB, et al. 2016. Changes in breathomics from a 1-year randomized smoking cessation trial of electronic cigarettes. European Journal of Clinical Investigation, 46: 698-706. PMID:27322745. doi:10.1111/eci.12651.

Camus M, Gallois G, and Marteau P. 2014. Ulcerative colitis and electronic cigarette: what's the matter? The American Journal of Gastroenterology, 109: 608-609. PMID:24698876. doi:10.1038/ ajg.2013.439.

Canadian Agency for Drugs and Technologies in Health. 2012. Electronic cigarettes: A review of the clinical evidence and safety. Ottawa, Ontario [online]: Available from cadth.ca/media/pdf/htis/ aug-2012/RC0380\%20E-cigarettes\%20Final.pdf.

Carnevale R, Sciarretta S, Violi F, Nocella C, Loffredo L, Perri L, et al. 2016. Acute impact of tobacco vs electronic cigarette smoking on oxidative stress and vascular function. Chest, 150: 606-612. PMID:27108682. doi:10.1016/j.chest.2016.04.012.

Casanova-Cháfer J, Gallart-Mateu D, Armenta S, and de la Guardia M. 2016. Preliminary results about the breath of passive smokers and vapers based on the use of portable air monitoring devices. Microchemical Journal, 126: 454-459. doi:10.1016/j.microc.2016.01.004.

Cervellati F, Muresan XM, Sticozzi C, Gambari R, Montagner G, Forman HJ, et al. 2014. Comparative effects between electronic and cigarette smoke in human keratinocytes and epithelial lung cells. Toxicology In Vitro, 28: 999-1005. PMID:24809892. doi:10.1016/j.tiv.2014. 04.012.

Cheng T. 2014. Chemical evaluation of electronic cigarettes. Tobacco Control, 23: ii11-ii17. PMID:24732157. doi:10.1136/tobaccocontrol-2013-051482.

Chu K-M, Cho CH, and Shin VY. 2013. Nicotine and gastrointestinal disorders: its role in ulceration and cancer development. Current Pharmaceutical Design, 19: 5-10. PMID:22950507. doi:10.2174/ 1381612811306010005.

Cibella F, Campagna D, Caponnetto P, Amaradio MD, Caruso M, Russo C, et al. 2016. Lung function and respiratory symptoms in a randomized smoking cessation trial of electronic cigarettes. Clinical Science, 130: 1929-1937. PMID:27543458. doi:10.1042/CS20160268.

Cooke A, Fergeson J, Bulkhi A, and Casale TB. 2015a. The electronic cigarette: the good, the bad, and the ugly. The Journal of Allergy and Clinical Immunology in Practice, 3: 498-505. PMID:26164573. doi:10.1016/j.jaip.2015.05.022. 
Cooke WH, Pokhrel A, Dowling C, Fogt DL, and Rickards CA. 2015b. Acute inhalation of vaporized nicotine increases arterial pressure in young non-smokers: a pilot study. Clinical Autonomic Research, 25: 267-270. PMID:26264837. doi:10.1007/s10286-015-0304-z.

Cravo AS, Bush J, Sharma G, Savioz R, Martin C, Craige S, et al. 2016. A randomised, parallel group study to evaluate the safety profile of an electronic vapour product over 12 weeks. Regulatory Toxicology and Pharmacology, 81: S1-S14. PMID:27769828. doi:10.1016/j.yrtph.2016.10.003.

Czogala J, Goniewicz ML, Fidelus B, Zielinska-Danch W, Travers MJ, and Sobczak A. 2014. Secondhand exposure to vapors from electronic cigarettes. Nicotine \& Tobacco Research, 16: 655662. PMID:24336346. doi:10.1093/ntr/ntt203.

Czoli CD, Reid JL, Rynard VL, and Hammond D. 2015. E-cigarettes in Canada-tobacco use in Canada: patterns and trends. 2015 edition. Special Supplement. Propel Centre for Population Health Impact, University of Waterloo, Waterloo, Ontario.

D'Ruiz CD, Graff DW, and Yan XS. 2015. Nicotine delivery, tolerability and reduction of smoking urge in smokers following short-term use of one brand of electronic cigarettes. BMC Public Health, 15: 991-1003. PMID:26424091. doi:10.1186/s12889-015-2349-2.

Davis B, Dang M, Kim J, and Talbot P. 2015. Nicotine concentrations in electronic cigarette refill and doit-yourself fluids. Nicotine \& Tobacco Research, 17: 134-141. PMID:24862971. doi:10.1093/ntr/ntu080.

Dawkins LE, and Corcoran O. 2014. Acute electronic cigarette use: nicotine delivery and subjective effects in regular users. Psychopharmacology, 231: 401-407. PMID:23978909. doi:10.1007/ s00213-013-3249-8.

Dawkins LE, Kimber CF, Doig M, Feyerabend C, and Corcoran O. 2016. Self-titration by experienced e-cigarette users: blood nicotine delivery and subjective effects. Psychopharmacology, 233: 29332941. PMID:27235016. doi:10.1007/s00213-016-4338-2.

Dicpinigaitis PV, Chang AL, Dicpinigaitis AJ, and Negassa A. 2016a. Effect of e-cigarette use on cough reflex sensitivity. Chest, 149: 161-165. PMID:26291648. doi:10.1378/chest.15-0817.

Dicpinigaitis PV, Chang AL, Dicpinigaitis AJ, and Negassa A. 2016b. Effect of electronic cigarette use on the urge-to-cough sensation. Nicotine \& Tobacco Research, 18: 1763-1765. PMID:26803150. doi:10.1093/ntr/ntw021.

Duong A, Steinmaus C, McHale CM, Vaughan CP, and Zhang L. 2011. Reproductive and developmental toxicity of formaldehyde: a systematic review. Mutation Research, 728: 118-138. PMID:21787879. doi:10.1016/j.mrrev.2011.07.003.

Durmowicz EL, Rudy SF, and Chen I-L. 2016. Electronic cigarettes: analysis of FDA adverse experience reports in non-users. Tobacco Control, 25: 242-242. PMID:25908596. doi:10.1136/tobaccocontrol2015-052235.

El Golli N, Dallagi Y, Rahali D, Rejeb I, and El Fazaa S. 2016a. Neurobehavioral assessment following e-cigarette refill liquid exposure in adult rats. Toxicology Mechanisms and Methods, 26: 435-442. PMID:27401341. doi:10.1080/15376516.2016.1193585.

El Golli N, Dkhili H, Dallagi Y, Rahali D, Lasram M, Bini-Dhouib I, et al. 2016b. Comparison between electronic cigarette refill liquid and nicotine on metabolic parameters in rats. Life Sciences, 146: 131138. PMID:26752340. doi:10.1016/j.lfs.2015.12.049. 
El Golli N, Jrad-Lamine A, Neffati H, Dkhili H, Rahali D, Dallagi Y, et al. 2016c. Impact of e-cigarette refill liquid exposure on rat kidney. Regulatory Toxicology and Pharmacology, 77: 109-116. PMID:26925498. doi:10.1016/j.yrtph.2016.02.012.

El Golli N, Rahali D, Jrad-Lamine A, Dallagi Y, Jallouli M, Bdiri Y, et al. 2016d. Impact of electroniccigarette refill liquid on rat testis. Toxicology Mechanisms and Methods, 26: 427-434. PMID:27098213. doi:10.3109/15376516.2016.1163448.

El-Hellani A, Salman R, El-Hage R, Talih S, Malek N, Baalbaki R, et al. 2016. Nicotine and carbonyl emissions from popular electronic cigarette products: correlation to liquid composition and design characteristics. Nicotine \& Tobacco Research, ntw280. PMID:27798087. doi:10.1093/ntr/ntw280.

Etter J-F. 2014. Levels of saliva cotinine in electronic cigarette users. Addiction, 109: 825-829. PMID:24401004. doi:10.1111/add.12475.

Etter J-F. 2015. Explaining the effects of electronic cigarettes on craving for tobacco in recent quitters. Drug and Alcohol Dependence, 148: 102-108. PMID:25592454. doi:10.1016/j.drugalcdep.2014. 12.030 .

Etter J-F. 2016. Throat hit in users of the electronic cigarette: an exploratory study. Psychology of Addictive Behaviors, 30: 93-100. PMID:26653150. doi:10.1037/adb0000137.

Etter J-F, and Eissenberg T. 2015. Dependence levels in users of electronic cigarettes, nicotine gums and tobacco cigarettes. Drug and Alcohol Dependence, 147: 68-75. PMID:25561385. doi:10.1016/j. drugalcdep.2014.12.007.

Farsalinos KE, and Romagna G. 2013. Chronic idiopathic neutrophilia in a smoker, relieved after smoking cessation with the use of electronic cigarette: a case report. Clinical Medicine Insights: Case Reports, 6: 15-21. PMID:23439796. doi:10.4137/CCRep.S11175.

Farsalinos KE, Romagna G, Allifranchini E, Ripamonti E, Bocchietto E, Todeschi S, et al. 2013. Comparison of the cytotoxic potential of cigarette smoke and electronic cigarette vapour extract on cultured myocardial cells. International Journal of Environmental Research and Public Health, 10: 5146-5162. PMID:24135821. doi:10.3390/ijerph10105146.

Farsalinos KE, Romagna G, Tsiapras D, Kyrzopoulos S, and Voudris V. 2014a. Characteristics, perceived side effects and benefits of electronic cigarette use: a worldwide survey of more than 19,000 consumers. International Journal of Environmental Research and Public Health, 11: 4356-4373. PMID:24758891. doi:10.3390/ijerph110404356.

Farsalinos KE, Spyrou A, Tsimopoulou K, Stefopoulos C, Romagna G, and Voudris V. 2014 b. Nicotine absorption from electronic cigarette use: comparison between first and new-generation devices. Scientific Reports, 4: 1-7. PMID:24569565. doi:10.1038/srep04133.

Farsalinos KE, Tsiapras D, Kyrzopoulos S, Savvopoulou M, and Voudris V. 2014c. Acute effects of using an electronic nicotine-delivery device (electronic cigarette) on myocardial function: comparison with the effects of regular cigarettes. BMC Cardiovascular Disorders, 14: 78-97. PMID:24958250. doi:10.1186/1471-2261-14-78.

Farsalinos KE, Gillman G, Poulas K, and Voudris V. 2015a. Tobacco-specific nitrosamines in electronic cigarettes: comparison between liquid and aerosol levels. International Journal of Environmental Research and Public Health, 12: 9046-9053. PMID:26264016. doi:10.3390/ ijerph120809046. 
Farsalinos KE, Kistler KA, Gillman G, and Voudris V. 2015b. Evaluation of electronic cigarette liquids and aerosol for the presence of selected inhalation toxins. Nicotine \& Tobacco Research, 17: 168-174. PMID:25180080. doi:10.1093/ntr/ntu176.

Farsalinos KE, Spyrou A, Stefopoulos C, Tsimopoulou K, Kourkoveli P, Tsiapras D, et al. 2015c. Nicotine absorption from electronic cigarette use: comparison between experienced consumers (vapers) and naïve users (smokers). Scientific Reports, 5: 11269. PMID:26082330. doi:10.1038/srep11269.

Farsalinos KE, Voudris V, and Poulas K. 2015d. E-cigarettes generate high levels of aldehydes only in 'dry puff conditions. Addiction, 110: 1352-1356. PMID:25996087. doi:10.1111/add.12942.

Farsalinos KE, Cibella F, Caponnetto P, Campagna D, Morjaria JB, Battaglia E, et al. 2016a. Effect of continuous smoking reduction and abstinence on blood pressure and heart rate in smokers switching to electronic cigarettes. Internal and Emergency Medicine, 11: 85-94. PMID:26749533. doi:10.1007/ s11739-015-1361-y.

Farsalinos KE, Poulas K, Voudris V, and Le Houezec J. 2016b. Electronic cigarette use in the European Union: analysis of a representative sample of 27460 Europeans from 28 countries. Addiction, 111: 2032-2040. PMID:27338716. doi:10.1111/add.13506.

Farsalinos KE, Yannovits N, Sarri T, Voudris V, and Poulas K. 2016c. Protocol proposal for, and evaluation of, consistency in nicotine delivery from the liquid to the aerosol of electronic cigarettes atomizers: regulatory implications. Addiction, 111: 1069-1076. PMID:26756124. doi:10.1111/add.13299.

Federal Emergency Management Agency. 2014. Electronic cigarette fires and explosions. US Fire Administration, Emmitsburg, Maryland, USA [online]: Available from usfa.fema.gov/downloads/ pdf/publications/electronic_cigarettes.pdf.

Ferrari M, Zanasi A, Nardi E, Maria A, Labate AMM, Ceriana P, et al. 2015. Short-term effects of a nicotine-free e-cigarette compared to a traditional cigarette in smokers and non-smokers. BMC Pulmonary Medicine, 15: 120. PMID:26459355. doi:10.1186/s12890-015-0106-z.

Flora JW, Meruva N, Huang CB, Wilkinson CT, Ballentine R, Smith DC, et al. 2016. Characterization of potential impurities and degradation products in electronic cigarette formulations and aerosols. Regulatory Toxicology and Pharmacology, 74: 1-11. PMID:26617410. doi:10.1016/j.yrtph. 2015.11.009.

Flouris AD, Poulianiti KP, Chorti MS, Jamurtas AZ, Kouretas D, Owolabi EO, et al. 2012. Acute effects of electronic and tobacco cigarette smoking on complete blood count. Food and Chemical Toxicology, 50: 3600-3603. PMID:22858449. doi:10.1016/j.fct.2012.07.025.

Flouris AD, Chorti MS, Poulianiti KP, Jamurtas AZ, Kostikas K, Tzatzarakis MN, et al. 2013. Acute impact of active and passive electronic cigarette smoking on serum cotinine and lung function. Inhalation Toxicology, 25: 91-101. PMID:23363041. doi:10.3109/08958378.2012.758197.

Food and Drug Administration. 2016. Vaporizers, e-cigarettes, and other electronic nicotine delivery systems (ENDS). Silver Spring, Maryland, USA [online]: Available from fda.gov/ TobaccoProducts/Labeling/ProductsIngredientsComponents/ucm456610.htm.

Foulds J, Veldheer S, Yingst J, Hrabovsky S, Wilson SJ, Nichols TT, et al. 2015. Development of a questionnaire for assessing dependence on electronic cigarettes among a large sample of ex-smoking e-cigarette users. Nicotine \& Tobacco Research, 17: 186-192. PMID:25332459. doi:10.1093/ntr/ ntu204. 
Franco T, Trapasso S, Puzzo L, and Allegra E. 2016. Electronic cigarette: role in the primary prevention of oral cavity cancer. Clinical Medicine Insights: Ear, Nose and Throat, 9: 7-12. PMID:27773997. doi:10.4137/cment.S40364.

Fuoco FC, Buonanno G, Stabile L, and Vigo P. 2014. Influential parameters on particle concentration and size distribution in the mainstream of e-cigarettes. Environmental Pollution, 184: 523-529. PMID:24172659. doi:10.1016/j.envpol.2013.10.010.

Gallart-Mateu D, Elbal L, Armenta S, and de la Guardia M. 2016. Passive exposure to nicotine from e-cigarettes. Talanta, 152: 329-334. PMID:26992528. doi:10.1016/j.talanta.2016.02.014.

Garcia-Arcos I, Geraghty P, Baumlin N, Campos M, Dabo AJ, Jundi B, et al. 2016. Chronic electronic cigarette exposure in mice induces features of COPD in a nicotine-dependent manner. Thorax, 71: 1119-1129. PMID:27558745. doi:10.1136/thoraxjnl-2015-208039.

Geiss O, Bianchi I, Barahona F, and Barrero-Moreno J. 2015. Characterisation of mainstream and passive vapours emitted by selected electronic cigarettes. International Journal of Hygiene and Environmental Health, 218: 169-180. PMID:25455424. doi:10.1016/j.ijheh.2014.10.001.

Göney G, Çok İ, Tamer U, Burgaz S, and Şengezer T. 2016. Urinary cotinine levels of electronic cigarette (e-cigarette) users. Toxicology Mechanisms and Methods, 26: 414-418. PMID:27278718. doi:10.3109/15376516.2016.1144127.

Goniewicz ML, Kuma T, Gawron M, Knysak J, and Kosmider L. 2013. Nicotine levels in electronic cigarettes. Nicotine \& Tobacco Research, 15: 158-166. PMID:22529223. doi:10.1093/ntr/nts103.

Goniewicz ML, Hajek P, and McRobbie H. 2014a. Nicotine content of electronic cigarettes, its release in vapour and its consistency across batches: regulatory implications. Addiction, 109: 500-507. PMID:24345184. doi:10.1111/add.12410.

Goniewicz ML, Knysak J, Gawron M, Kosmider L, Sobczak A, Kurek J, et al. 2014b. Levels of selected carcinogens and toxicants in vapour from electronic cigarettes. Tobacco Control, 23: 133-139. PMID:23467656. doi:10.1136/tobaccocontrol-2012-050859.

Goniewicz ML, Gupta R, Lee YH, Reinhardt S, Kim S, Kim B, et al. 2015. Nicotine levels in electronic cigarette refill solutions: a comparative analysis of products from the U.S., Korea, and Poland. The International Journal of Drug Policy, 26: 583-588. PMID:25724267. doi:10.1016/j.drugpo.2015.01.020.

Goniewicz ML, Gawron M, Smith DM, Peng M, Jacob P, III, and Benowitz NL. 2017. Exposure to nicotine and selected toxicants in cigarette smokers who switched to electronic cigarettes: a longitudinal within-subjects observational study. Nicotine \& Tobacco Research, 19: 160-167. PMID:27613896. doi:10.1093/ntr/ntw160.

Grace RC, Kivell BM, and Laugesen M. 2015. Estimating cross-price elasticity of e-cigarettes using a simulated demand procedure. Nicotine \& Tobacco Research, 17: 592-598. PMID:25548256. doi:10.1093/ntr/ntu268.

Grana R, Benowitz N, and Glantz SA. 2014. E-cigarettes: a scientific review. Circulation, 129: 19721986. PMID:24821826. doi:10.1161/CIRCULATIONAHA.114.007667.

Hahn J, Monakhova YB, Hengen J, Kohl-Himmelseher M, Schüssler J, Hahn H, et al. 2014. Electronic cigarettes: overview of chemical composition and exposure estimation. Tobacco Induced Diseases, 12: 23. PMID:25620905. doi:10.1186/s12971-014-0023-6. 
Hajek P. 2014. Electronic cigarettes have a potential for huge public health benefit. BMC Medicine, 12: 225. PMID:25491742. doi:10.1186/s12916-014-0225-Z.

Hajek P, Etter J-F, Benowitz N, Eissenberg T, and McRobbie H. 2014. Electronic cigarettes: review of use, content, safety, effects on smokers and potential for harm and benefit. Addiction, 109: 18011810. PMID:25078252. doi:10.1111/add.12659.

Hajek P, Goniewicz ML, Phillips A, Smith KM, West O, and McRobbie H. 2015. Nicotine intake from electronic cigarettes on initial use and after 4 weeks of regular use. Nicotine \& Tobacco Research, 17: 175-179. PMID:25122503. doi:10.1093/ntr/ntu153.

Hammett E, Veldheer S, Yingst J, Hrabovsky S, and Foulds J. 2017. Characteristics, use patterns and perceptions of electronic cigarette users who were never traditional cigarette smokers. Addictive Behaviors, 65: 92-97. PMID:27816045. doi:10.1016/j.addbeh.2016.10.007.

Hecht SS, Carmella SG, Kotandeniya D, Pillsbury ME, Chen M, Ransom BWS, et al. 2015. Evaluation of toxicant and carcinogen metabolites in the urine of e-cigarette users versus cigarette smokers. Nicotine \& Tobacco Research, 17: 704-709. PMID:25335945. doi:10.1093/ntr/ntu218.

Herrington JS, and Myers C. 2015. Electronic cigarette solutions and resultant aerosol profiles. Journal of Chromatography A, 1418: 192-199. PMID:26422308. doi:10.1016/j.chroma. 2015.09.034.

Hess CA, Olmedo P, Navas-Acien A, Goessler W, Cohen JE, and Rule AM. 2017. E-cigarettes as a source of toxic and potentially carcinogenic metals. Environmental Research, 152: 221-225. PMID:27810679. doi:10.1016/j.envres.2016.09.026.

Heyder J. 2004. Deposition of inhaled particles in the human respiratory tract and consequences for regional targeting in respiratory drug delivery. Proceedings of the American Thoracic Society, 1: 315-320. PMID:16113452. doi:10.1513/pats.200409-046TA.

Higham A, Rattray NJW, Dewhurst JA, Trivedi DK, Fowler SJ, Goodacre R, et al. 2016. Electronic cigarette exposure triggers neutrophil inflammatory responses. Respiratory Research, 17: 56. PMID:27184092. doi:10.1186/s12931-016-0368-x.

Hom S, Chen L, Wang T, Ghebrehiwet B, Yin W, and Rubenstein DA. 2016. Platelet activation, adhesion, inflammation, and aggregation potential are altered in the presence of electronic cigarette extracts of variable nicotine concentrations. Platelets, 27: 694-702. PMID:27096416. doi:10.3109/ 09537104.2016.1158403.

Husari A, Shihadeh A, Talih S, Hashem Y, El Sabban M, and Zaatari G. 2016. Acute exposure to electronic and combustible cigarette aerosols: effects in an animal model and in human alveolar cells. Nicotine \& Tobacco Research, 18: 613-619. PMID:26272212. doi:10.1093/ntr/ ntv169.

Hutzler C, Paschke M, Kruschinski S, Henkler F, Hahn J, and Luch A. 2014. Chemical hazards present in liquids and vapors of electronic cigarettes. Archives of Toxicology, 88: 1295-1308. PMID:24958024. doi:10.1007/s00204-014-1294-7.

Hwang JH, Lyes M, Sladewski K, Enany S, McEachern E, Mathew DP, et al. 2016. Electronic cigarette inhalation alters innate immunity and airway cytokines while increasing the virulence of colonizing bacteria. Journal of Molecular Medicine, 94: 667-679. PMID:26804311. doi:10.1007/s00109016-1378-3. 
Iskandar AR, Gonzalez-Suarez I, Majeed S, Marescotti D, Sewer A, Xiang Y, et al. 2016. A framework for in vitro systems toxicology assessment of e-liquids. Toxicology Mechanisms and Methods, 26: 389-413. PMID:27117495. doi:10.3109/15376516.2016.1170251.

Jackson KJ, Muldoon PP, De Biasi M, and Damaj MI. 2015. New mechanisms and perspectives in nicotine withdrawal. Neuropharmacology, 96: 223-234. PMID:25433149. doi:10.1016/j. neuropharm.2014.11.009.

Jensen RP, Luo W, Pankow JF, Strongin RM, and Peyton DH. 2015. Hidden formaldehyde in e-cigarette aerosols. New England Journal of Medicine, 372: 392-394. PMID:25607446. doi:10.1056/ NEJMc1413069.

Ji EH, Sun B, Zhao T, Shu S, Chang CH, Messadi D, et al. 2016. Characterization of electronic cigarette aerosol and its induction of oxidative stress response in oral keratinocytes. PLoS ONE, 11: e0169380. PMID:27223106. doi:10.1371/journal.pone.0154447.

Jo S-H, and Kim K-H. 2016. Development of a sampling method for carbonyl compounds released due to the use of electronic cigarettes and quantitation of their conversion from liquid to aerosol. Journal of Chromatography A, 1429: 369-373. PMID:26748866. doi:10.1016/j.chroma.2015.12.061.

Kalkhoran S, and Glantz SA. 2015. Modeling the health effects of expanding e-cigarette sales in the United States and United Kingdom: a Monte Carlo analysis. JAMA Internal Medicine, 175: 16711680. PMID:26322924. doi:10.1001/jamainternmed.2015.4209.

Kavvalakis MP, Stivaktakis PD, Tzatzarakis MN, Kouretas D, and Liesivuori J. 2015. Multicomponent analysis of replacement liquids of electronic cigarettes using chromatographic techniques. Journal of Analytical Toxicology, 39: 262-269. PMID:25681325. doi:10.1093/jat/bkv002.

Kienhuis AS, Soeteman-Hernandez LG, Bos PMJ, Cremers HWJM, Klerx WN, and Talhout R. 2015. Potential harmful health effects of inhaling nicotine-free shisha-pen vapor: a chemical risk assessment of the main components propylene glycol and glycerol. Tobacco Induced Diseases, 13: 1-6. PMID:26120296. doi:10.1186/s12971-015-0038-7.

Kim H-J, and Shin H-S. 2013. Determination of tobacco-specific nitrosamines in replacement liquids of electronic cigarettes by liquid chromatography-tandem mass spectrometry. Journal of Chromatography A, 1291: 48-55. PMID:23602640. doi:10.1016/j.chroma.2013.03.035.

Kim H, Lim J, Buehler SS, Brinkman MC, Johnson NM, Wilson L, et al. 2016. Role of sweet and other flavours in liking and disliking of electronic cigarettes. Tobacco Control, 25: ii55-ii61. PMID:27708124. doi:10.1136/tobaccocontrol-2016-053221.

Kong AY, Derrick JC, Abrantes AS, and Williams RS. 2016. What is included with your online e-cigarette order? An analysis of e-cigarette shipping, product and packaging features. Tobacco Control. PMID:27357936. doi:10.1136/tobaccocontrol-2016-053061.

Kosmider L, Sobczak A, Fik M, Knysak J, Zaciera M, Kurek J, et al. 2014. Carbonyl compounds in electronic cigarette vapors: effects of nicotine solvent and battery output voltage. Nicotine \& Tobacco Research, 16: 1319-1326. PMID:24832759. doi:10.1093/ntr/ntu078.

Kotandeniya D, Carmella SG, Pillsbury ME, and Hecht SS. 2015. Combined analysis of $N^{\prime}$-nitrosonornicotine and 4-(methylnitrosamino)-1-(3-pyridyl)-1-butanol in the urine of cigarette smokers and e-cigarette users. Journal of Chromatography B, 1007: 121-126. PMID:26595795. doi:10.1016/j.jchromb.2015.10.012. 
Laugesen M. 2008. Second safety report on the Ruyan ${ }^{\circledR}$ e-cigarette. Health New Zealand Ltd, Lyttelton, Christchurch, New Zeland.

Lauterstein DE, Tijerina PB, Corbett K, Akgol Oksuz B, Shen SS, Gordon T, et al. 2016. Frontal cortex transcriptome analysis of mice exposed to electronic cigarettes during early life stages. International Journal of Environmental Research and Public Health, 13: 417. PMID:27077873. doi:10.3390/ ijerph 13040417.

Lee YH, Gawron M, and Goniewicz ML. 2015. Changes in puffing behavior among smokers who switched from tobacco to electronic cigarettes. Addictive Behaviors, 48: 1-4. PMID:25930009. doi:10.1016/j.addbeh.2015.04.003.

Leigh NJ, Lawton RI, Hershberger PA, and Goniewicz ML. 2016. Flavourings significantly affect inhalation toxicity of aerosol generated from electronic nicotine delivery systems (ENDS). Tobacco Control, 25: ii81-ii87. PMID:27633767. doi:10.1136/tobaccocontrol-2016-053205.

Lerner CA, Sundar IK, Watson RM, Elder A, Jones R, Done D, et al. 2015a. Environmental health hazards of e-cigarettes and their components: oxidants and copper in e-cigarette aerosols. Environmental Pollution, 198: 100-107. PMID:25577651. doi:10.1016/j.envpol.2014.12.033.

Lerner CA, Sundar IK, Yao H, Gerloff J, Ossip DJ, McIntosh S, et al. 2015b. Vapors produced by electronic cigarettes and e-juices with flavorings induce toxicity, oxidative stress, and inflammatory response in lung epithelial cells and in mouse lung. PLoS ONE, 10: 1-27. PMID:25658421. doi:10.1371/journal.pone.0116732.

Lerner CA, Rutagarama P, Ahmad T, Sundar IK, Elder A, and Rahman I. 2016. Electronic cigarette aerosols and copper nanoparticles induce mitochondrial stress and promote DNA fragmentation in lung fibroblasts. Biochemical and Biophysical Research Communications, 477: 620-625. PMID:27343559. doi:10.1016/j.bbrc.2016.06.109.

Levy DT, Cummings KM, Villanti AC, Niaura R, Abrams DB, Fong GT, et al. 2017. A framework for evaluating the public health impact of e-cigarettes and other vaporized nicotine products. Addiction, 112: 8-17. PMID:27109256. doi:10.1111/add.13394.

Lim HB, and Kim SH. 2014. Inhalation of e-cigarette cartridge solution aggravates allergen-induced airway inflammation and hyper-responsiveness in mice. Toxicological Research, 30: 13-18. PMID:24795794. doi:10.5487/TR.2014.30.1.013.

Lisko JG, Tran H, Stanfill SB, Blount BC, and Watson CH. 2015. Chemical composition and evaluation of nicotine, tobacco alkaloids, $\mathrm{pH}$, and selected flavors in e-cigarette cartridges and refill solutions. Nicotine \& Tobacco Research, 17: 1270-1278. PMID:25636907. doi:10.1093/ntr/ ntu279.

Loewenstein DK, and Middlekauff HR. 2017. Electronic cigarette device-related hazards: a call for immediate FDA regulation. American Journal of Preventive Medicine, 52: 229-231. PMID:27720343. doi:10.1016/j.amepre.2016.08.030.

Long GA. 2014. Comparison of select analytes in exhaled aerosol from e-cigarettes with exhaled smoke from a conventional cigarette and exhaled breaths. International Journal of Environmental Research and Public Health, 11: 11177-11191. PMID:25350011. doi:10.3390/ijerph11111177. 
Manigrasso M, Buonanno G, Stabile L, Morawska L, and Avino P. 2015. Particle doses in the pulmonary lobes of electronic and conventional cigarette users. Environmental Pollution, 202: 24-31. doi:10.1016/j.envpol.2015.03.008.

Manzoli L, Flacco ME, Fiore M, La Vecchia C, Marzuillo C, Gualano MR, et al. 2015. Electronic cigarettes efficacy and safety at 12 months: cohort study. PLoS ONE, 10: e0129443. PMID:26061661. doi:10.1371/journal.pone.0129443.

Manzoli L, Flacco ME, Ferrante M, La Vecchia C, Siliquini R, Ricciardi W, et al. 2017. Cohort study of electronic cigarette use: effectiveness and safety at 24 months. Tobacco Control, 26: 284-292. PMID:27272748. doi:10.1136/tobaccocontrol-2015-052822.

Margham J, McAdam K, Forster M, Liu C, Wright C, Mariner D, et al. 2016. Chemical composition of aerosol from an e-cigarette: a quantitative comparison with cigarette smoke. Chemical Research in Toxicology, 29: 1662-1678. PMID:27641760. doi:10.1021/acs.chemrestox.6b00188.

Marini S, Buonanno G, Stabile L, and Ficco G. 2014. Short-term effects of electronic and tobacco cigarettes on exhaled nitric oxide. Toxicology and Applied Pharmacology, 278: 9-15. PMID:24732441. doi:10.1016/j.taap.2014.04.004.

Martin EM, Clapp PW, Rebuli ME, Pawlak EA, Glista-Baker E, Benowitz NL, et al. 2016. E-cigarette use results in suppression of immune and inflammatory-response genes in nasal epithelial cells similar to cigarette smoke. American Journal of Physiology_Lung Cellular and Molecular Physiology, 311: L135-L144. PMID:27288488. doi:10.1152/ajplung.00170.2016.

Martini D, Del Bo C, Tassotti M, Riso P, Del Rio D, Brighenti F, et al. 2016. Coffee consumption and oxidative stress: a review of human intervention studies. Molecules, 21: 979. PMID:27483219. doi:10.3390/molecules21080979.

McAuley TR, Hopke PK, Zhao J, and Babaian S. 2012. Comparison of the effects of e-cigarette vapor and cigarette smoke on indoor air quality. Inhalation Toxicology, 24: 850-857. PMID:23033998. doi:10.3109/08958378.2012.724728.

McGrath-Morrow SA, Hayashi M, Aherrera A, Lopez A, Malinina A, Collaco JM, et al. 2015. The effects of electronic cigarette emissions on systemic cotinine levels, weight and postnatal lung growth in neonatal mice. PLoS ONE, 10: e0118344. PMID:25706869. doi:10.1371/journal. pone.0118344.

McQueen A, Tower S, and Sumner W. 2011. Interviews with "vapers": implications for future research with electronic cigarettes. Nicotine \& Tobacco Research, 13: 860-867. PMID:21571692. doi:10.1093/ntr/ntr088.

McRobbie H, Phillips A, Goniewicz ML, Smith KM, Knight-West O, Przulj D, et al. 2015. Effects of switching to electronic cigarettes with and without concurrent smoking on exposure to nicotine, carbon monoxide, and acrolein. Cancer Prevention Research, 8: 873-878. PMID:26333731. doi:10.1158/ 1940-6207.CAPR-15-0058.

Mikheev VB, Brinkman MC, Granville CA, Gordon SM, and Clark PI. 2016. Real-time measurement of electronic cigarette aerosol size distribution and metals content analysis. Nicotine \& Tobacco Research, 18: 1895-1902. PMID:27146638. doi:10.1093/ntr/ntw128. 
Misra M, Leverette RD, Cooper BT, Bennett MB, and Brown SE. 2014. Comparative in vitro toxicity profile of electronic and tobacco cigarettes, smokeless tobacco and nicotine replacement therapy products: e-liquids, extracts and collected aerosols. International Journal of Environmental Research and Public Health, 11: 11325-11347. PMID:25361047. doi:10.3390/ ijerph11111325.

Moses E, Wang T, Corbett S, Jackson GR, Drizik E, Perdomo C, et al. 2017. Molecular impact of electronic cigarette aerosol exposure in human bronchial epithelium. Toxicological Sciences, 155: 248-257. PMID:27701119. doi:10.1093/toxsci/kfw198.

Musk AW, and de Klerk NH. 2003. History of tobacco and health. Respirology, 8: 286-290. PMID:14528877. doi:10.1046/j.1440-1843.2003.00483.x.

Neilson L, Mankus C, Thorne D, Jackson G, DeBay J, and Meredith C. 2015. Development of an in vitro cytotoxicity model for aerosol exposure using 3D reconstructed human airway tissue; application for assessment of e-cigarette aerosol. Toxicology In Vitro, 29: 1952-1962. PMID:26176715. doi:10.1016/j.tiv.2015.05.018.

Nides MA, Leischow SJ, Bhatter M, and Simmons M. 2014. Nicotine blood levels and short-term smoking reduction with an electronic nicotine delivery system. American Journal of Health Behaviour, 38: 265-274. PMID:24629555. doi:10.5993/AJHB.38.2.12.

Nutt DJ, Phillips LD, Balfour D, Curran HV, Dockrell M, Foulds J, et al. 2014. Estimating the harms of nicotine-containing products using the MCDA approach. European Addiction Research, 20: 218-225. PMID:24714502. doi:10.1159/000360220.

O’Connell G, Colard S, Cahours X, and Pritchard JD. 2015. An assessment of indoor air quality before, during and after unrestricted use of e-cigarettes in a small room. International Journal of Environmental Research and Public Health, 12: 4889-4907. PMID:25955526. doi:10.3390/ ijerph120504889.

O’Connell G, Graff DW, and D'Ruiz CD. 2016. Reductions in biomarkers of exposure (BoE) to harmful or potentially harmful constituents (HPHCs) following partial or complete substitution of cigarettes with electronic cigarettes in adult smokers. Toxicology Mechanisms and Methods, 26: 443-454. PMID:27401591. doi:10.1080/15376516.2016.1196282.

Pacifici R, Pichini S, Graziano S, Pellegrini M, Massaro G, and Beatrice F. 2015. Successful nicotine intake in medical assisted use of e-cigarettes: a pilot study. International Journal of Environmental Research and Public Health, 12: 7638-7646. PMID:26184244. doi:10.3390/ijerph120707638.

Pagano T, DiFrancesco AG, Smith SB, George J, Wink G, Rahman I, et al. 2016. Determination of nicotine content and delivery in disposable electronic cigarettes available in the United States by gas chromatography-mass spectrometry. Nicotine \& Tobacco Research, 18: 700-707. PMID:26045251. doi:10.1093/ntr/ntv120.

Page F, Hamnett N, Wearn C, Hardwicke J, and Moiemen N. 2016. The acute effects of electronic cigarette smoking on the cutaneous circulation. Journal of Plastic, Reconstructive and Aesthetic Surgery, 69: 575-577. PMID:26776350. doi:10.1016/j.bjps.2015.12.015.

Palpant NJ, Hofsteen P, Pabon L, Reinecke H, and Murry CE. 2015. Cardiac development in zebrafish and human embryonic stem cells is inhibited by exposure to tobacco cigarettes and e-cigarettes. PLoS ONE, 10: e0126259. PMID:25978043. doi:10.1371/journal.pone.0126259. 
Panitz D, Swamy H, and Nehrke K. 2015. A C. elegans model of electronic cigarette use: physiological effects of e-liquids in nematodes. BMC Pharmacology and Toxicology, 16: 32-42. PMID:26637209. doi:10.1186/s40360-015-0030-0.

Patel D, Davis KC, Cox S, Bradfield B, King BA, Shafer P, et al. 2016. Reasons for current E-cigarette use among U.S. adults. Preventive Medicine, 93: 14-20. PMID:27612572. doi:10.1016/j.ypmed.2016.09.011.

Pauly J, Li Q, and Barry MB. 2007. Tobacco-free electronic cigarettes and cigars deliver nicotine and generate concern. Tobacco Control, 16: 357. PMID:17897997. doi:10.1136/tc.2006.019687.

Pauly JR, and Slotkin TA. 2008. Maternal tobacco smoking, nicotine replacement and neurobehavioural development. Acta Paediatrica, 97: 1331-1337. PMID:18554275. doi:10.1111/ j.1651-2227.2008.00852.x.

Pellegrino RM, Tinghino B, Mangiaracina G, Marani A, Vitali M, Protano C, et al. 2012. Electronic cigarettes: an evaluation of exposure to chemicals and fine particulate matter (PM). Annali Di Igiene, 24: 279-288. PMID:22913171.

Pisinger C, and Døssing M. 2014. A systematic review of health effects of electronic cigarettes. Preventive Medicine, 69: 248-260. PMID:25456810. doi:10.1016/j.ypmed.2014.10.009.

Polosa R. 2015. Electronic cigarette use and harm reversal: emerging evidence in the lung. BMC Medicine, 13: 54-58. PMID:25857426. doi:10.1186/s12916-015-0298-3.

Polosa R, Morjaria J, Caponnetto P, Caruso M, Strano S, Battaglia E, et al. 2014. Effect of smoking abstinence and reduction in asthmatic smokers switching to electronic cigarettes: evidence for harm reversal. International Journal of Environmental Research and Public Health, 11: 4965-4977. PMID:24814944. doi:10.3390/ijerph110504965.

Polosa R, Morjaria JB, Caponnetto P, Caruso M, Campagna D, Amaradio MD, et al. 2016. Persisting long term benefits of smoking abstinence and reduction in asthmatic smokers who have switched to electronic cigarettes. Discovery Medicine, 21: 99-108. PMID:27011045.

Ponzoni L, Moretti M, Sala M, Fasoli F, Mucchietto V, Lucini V, et al. 2015. Different physiological and behavioural effects of e-cigarette vapour and cigarette smoke in mice. European Neuropsychopharmacology, 25: 1775-1786. PMID:26141510. doi:10.1016/j.euroneuro.2015.06.010.

Putzhammer R, Doppler C, Jakschitz T, Heinz K, Förste J, Danzl K, et al. 2016. Vapours of US and EU market leader electronic cigarette brands and liquids are cytotoxic for human vascular endothelial cells. PLoS ONE, 11: e0157337. PMID:27351725. doi:10.1371/journal.pone.0157337.

Rahman MA, Hann N, Wilson A, Mnatzaganian G, and Worrall-Carter L. 2015. E-cigarettes and smoking cessation: evidence from a systematic review and meta-analysis. PLoS ONE, 10: e0122544. PMID:25822251. doi:10.1371/journal.pone.0122544.

Ramôa CP, Hiler MM, Spindle TR, Lopez AA, Karaoghlanian N, Lipato T, et al. 2016. Electronic cigarette nicotine delivery can exceed that of combustible cigarettes: a preliminary report. Tobacco Control, 25: e6-e9. PMID:26324250. doi:10.1136/tobaccocontrol-2015-052447.

Reddy AM, Seo JH, Ryu SY, Kim YS, Kim YS, Min KR, et al. 2004. Cinnamaldehyde and 2-methoxycinnamaldehyde as NF- $\mathrm{BB}$ inhibitors from Cinnamomum cassia. Planta Medica, 70: 823827. PMID:15503352. doi:10.1055/s-2004-827230. 
Reuther WJ, Hale B, Matharu J, Blythe JN, and Brennan PA. 2016. Do you mind if I vape? Immediate effects of electronic cigarettes on perfusion in buccal mucosal tissue-a pilot study. British Journal of Oral and Maxillofacial Surgery, 54: 338-341. PMID:26809237. doi:10.1016/j. bjoms.2015.12.001.

Ricciardolo FLM. 2003. Multiple roles of nitric oxide in the airways. Thorax, 58: 175-182. PMID:12554905. doi:10.1136/thorax.58.2.175.

Romagna G, Allifranchini E, Bocchietto E, Todeschi S, Esposito M, and Farsalinos KE. 2013. Cytotoxicity evaluation of electronic cigarette vapor extract on cultured mammalian fibroblasts (ClearStream-LIFE): comparison with tobacco cigarette smoke extract. Inhalation Toxicology, 25: 354-361. PMID:23742112. doi:10.3109/08958378.2013.793439.

Russo C, Cibella F, Caponnetto P, Campagna D, Maglia M, Frazzetto E, et al. 2016. Evaluation of post cessation weight gain in a 1-year randomized smoking cessation trial of electronic cigarettes. Scientific Reports, 6: 18763. PMID:26729619. doi:10.1038/srep18763.

Salturk Z, Çakır Ç, Sünnetçi G, Atar Y, Kumral TL, Yıldırım G, et al. 2015. Effects of electronic nicotine delivery system on larynx: experimental study. Journal of Voice, 29: 560-563. PMID:25704471. doi:10.1016/j.jvoice.2014.10.013.

Sancilio S, Gallorini M, Cataldi A, and di Giacomo V. 2016. Cytotoxicity and apoptosis induction by e-cigarette fluids in human gingival fibroblasts. Clinical Oral Investigations, 20: 477-483. PMID:26239821. doi:10.1007/s00784-015-1537-x.

Schaal C, and Chellappan S. 2016. Nicotine-mediated regulation of nicotinic acetylcholine receptors in non-small cell lung adenocarcinoma by E2F1 and STAT1 transcription factors. PLoS ONE, 11: e0156451. PMID:27228072. doi:10.1371/journal.pone.0156451.

Scheffler S, Dieken H, Krischenowski O, and Aufderheide M. 2015a. Cytotoxic evaluation of e-liquid aerosol using different lung-derived cell models. International Journal of Environmental Research and Public Health, 12: 12466-12474. PMID:26445056. doi:10.3390/ijerph121012466.

Scheffler S, Dieken H, Krischenowski O, Förster C, Branscheid D, and Aufderheide M. 2015b. Evaluation of e-cigarette liquid vapor and mainstream cigarette smoke after direct exposure of primary human bronchial epithelial cells. International Journal of Environmental Research and Public Health, 12: 3915-3925. PMID:25856554. doi:10.3390/ijerph120403915.

Schober W, Szendrei K, Matzen W, Osiander-Fuchs H, Heitmann D, Schettgen T, et al. 2014. Use of electronic cigarettes (e-cigarettes) impairs indoor air quality and increases FeNO levels of e-cigarette consumers. International Journal of Hygiene and Environmental Health, 217: 628-637. PMID:24373737. doi:10.1016/j.ijheh.2013.11.003.

Schweitzer KS, Chen SX, Law S, Van Demark M, Poirier C, Justice MJ, et al. 2015. Endothelial disruptive proinflammatory effects of nicotine and e-cigarette vapor exposures. American Journal of Physiology-Lung, Cellular, and Molecular Physiology, 309: L175-L187. PMID:25979079. doi:10.1152/ajplung.00411.2014.

Sherwood CL, and Boitano S. 2016. Airway epithelial cell exposure to distinct e-cigarette liquid flavorings reveals toxicity thresholds and activation of CFTR by the chocolate flavoring 2,5-dimethypyrazine. Respiratory Research, 17: 57. PMID:27184162. doi:10.1186/s12931-016-0369-9. 
Shibamoto T. 2014. Diacetyl: occurrence, analysis, and toxicity. Journal of Agricultural and Food Chemistry, 62: 4048-4053. PMID:24738917. doi:10.1021/jf500615u.

Shivalingappa PC, Hole R, Van Westphal C, and Vij N. 2016. Airway exposure to e-cigarette vapors impairs autophagy and induces aggresome formation. Antioxidants \& Redox Signaling, 24: 186204. PMID:26377848. doi:10.1089/ars.2015.6367.

Sleiman M, Logue JM, Montesinos VN, Russell ML, Litter MI, Gundel LA, et al. 2016. Emissions from electronic cigarettes: key parameters affecting the release of harmful chemicals. Environmental Science and Technology, 50: 9644-9651. PMID:27461870. doi:10.1021/acs. est.6b01741.

Smith D, Aherrera A, Lopez A, Neptune E, Winickoff JP, Klein JD, et al. 2015. Adult behavior in male mice exposed to e-cigarette nicotine vapors during late prenatal and early postnatal life. PLoS ONE, 10: e0137953. PMID:26372012. doi:10.1371/journal.pone.0137953.

Sosnowski TR, and Kramek-Romanowska K. 2016. Predicted deposition of e-cigarette aerosol in the human lungs. Journal of Aerosol Medicine and Pulmonary Drug Delivery, 29: 299-309. PMID:26907696. doi:10.1089/jamp.2015.1268.

Spindle TR, Breland AB, Karaoghlanian NV, Shihadeh AL, and Eissenberg T. 2015. Preliminary results of an examination of electronic cigarette user puff topography: the effect of a mouthpiecebased topography measurement device on plasma nicotine and subjective effects. Nicotine \& Tobacco Research, 17: 142-149. PMID:25239957. doi:10.1093/ntr/ntu186.

St. Helen G, Havel C, Dempsey DA, Jacob P, III, and Benowitz NL. 2016. Nicotine delivery, retention and pharmacokinetics from various electronic cigarettes. Addiction, 111: 535-544. PMID:26430813. doi:10.1111/add.13183.

Sussan TE, Gajghate S, Thimmulappa RK, Ma J, Kim J-H, Sudini K, et al. 2015. Exposure to electronic cigarettes impairs pulmonary anti-bacterial and anti-viral defenses in a mouse model. PLoS ONE, 10: e0116861. PMID:25651083. doi:10.1371/journal.pone.0116861.

Swan GE, and Lessov-Schlaggar CN. 2007. The effects of tobacco smoke and nicotine on cognition and the brain. Neuropsychology Review, 17: 259-273. PMID:17690985. doi:10.1007/s11065-007-9035-9.

Szołtysek-Bołdys I, Sobczak A, Zielińska-Danch W, Bartoń A, Koszowski B, and Kośmider L. 2014. Influence of inhaled nicotine source on arterial stiffness. Przeglad Lekarski, 71: 572-575. PMID:25799846.

Talih S, Balhas Z, Eissenberg T, Salman R, Karaoghlanian N, El-Hellani A, et al. 2015. Effects of user puff topography, device voltage, and liquid nicotine concentration on electronic cigarette nicotine yield: measurements and model predictions. Nicotine \& Tobacco Research, 17: 150-157. PMID:25187061. doi:10.1093/ntr/ntu174.

Talih S, Balhas Z, Salman R, Karaoghlanian N, and Shihadeh A. 2016. "Direct dripping": a hightemperature, high-formaldehyde emission electronic cigarette use method. Nicotine \& Tobacco Research, 18: 453-459. PMID:25863521. doi:10.1093/ntr/ntv080.

Tartell HE. 2015. Are e-cigarettes a safe alternative to smoking? Using airway cell cultures to assess early indicators of COPD progression. Inquiries Journal, 7: 1-2. 
Taylor M, Carr T, Oke O, Jaunky T, Breheny D, Lowe F, et al. 2016. E-cigarette aerosols induce lower oxidative stress in vitro when compared to tobacco smoke. Toxicology Mechanisms and Methods, 26: 465-476. PMID:27690198. doi:10.1080/15376516.2016.1222473.

Tayyarah R, and Long GA. 2014. Comparison of select analytes in aerosol from e-cigarettes with smoke from conventional cigarettes and with ambient air. Regulatory Toxicology and Pharmacology, 70: 704-710. PMID:25444997. doi:10.1016/j.yrtph.2014.10.010.

Teasdale JE, Newby AC, Timpson NJ, Munafò MR, and White SJ. 2016. Cigarette smoke but not electronic cigarette aerosol activates a stress response in human coronary artery endothelial cells in culture. Drug and Alcohol Dependence, 163: 256-260. PMID:27137404. doi:10.1016/j.drugalcdep.2016.04.020.

Tierney PA, Karpinski CD, Brown JE, Luo W, and Pankow JF. 2016. Flavour chemicals in electronic cigarette fluids. Tobacco Control, 25: e10-e15. PMID:25877377. doi:10.1136/tobaccocontrol2014-052175.

Trassierra CV, Cardellini F, Buonanno G, and De Felice P. 2015. On the interaction between radon progeny and particles generated by electronic and traditional cigarettes. Atmospheric Environment, 106: 442-450. doi:10.1016/j.atmosenv.2014.06.017.

Trtchounian A, Williams M, and Talbot P. 2010. Conventional and electronic cigarettes (e-cigarettes) have different smoking characteristics. Nicotine \& Tobacco Research, 12: 905-912. PMID:20644205. doi:10.1093/ntr/ntq114.

Uchiyama S, Ohta K, Inaba Y, and Kunugita N. 2013. Determination of carbonyl compounds generated from the e-cigarette using coupled silica cartridges impregnated with hydroquinone and 2,4-dinitrophenylhydrazine, followed by high-performance liquid chromatography. Analytical Sciences, 29: 1219-1222. PMID:24334991. doi:10.2116/analsci.29.1219.

Vahlkvist S, Sinding M, Skamstrup K, and Bisgaard H. 2006. Daily home measurements of exhaled nitric oxide in asthmatic children during natural birch pollen exposure. The Journal of Allergy and Clinical Immunology, 117: 1272-1276. PMID:16750986. doi:10.1016/j.jaci.2006.03.018.

van Staden SR, Groenewald M, Engelbrecht R, Becker PJ, and Hazelhurst LT. 2013. Carboxyhaemoglobin levels, health and lifestyle perceptions in smokers converting from tobacco cigarettes to electronic cigarettes. South African Medical Journal, 103: 865-868. PMID:24148175. doi:10.7196/samj.6887.

Vansickel AR, and Eissenberg T. 2013. Electronic cigarettes: effective nicotine delivery after acute administration. Nicotine \& Tobacco Research, 15: 267-270. PMID:22311962. doi:10.1093/ntr/ ntr316.

Vansickel AR, Weaver MF, and Eissenberg T. 2012. Clinical laboratory assessment of the abuse liability of an electronic cigarette. Addiction, 107: 1493-1500. PMID:22229871. doi:10.1111/ j.1360-0443.2012.03791.x.

Vardavas CI, Anagnostopoulos N, Kougias M, Evangelopoulou V, Connolly GN, and Behrakis PK. 2012. Short-term pulmonary effects of using an electronic cigarette: impact on respiratory flow resistance, impedance, and exhaled nitric oxide. Chest, 141: 1400-1406. PMID:22194587. doi:10.1378/ chest.11-2443. 
Vélez de Mendizábal N, Jones DR, Jahn A, Bies RR, and Brown JW. 2015. Nicotine and cotinine exposure from electronic cigarettes: a population approach. Clinical Pharmacokinetics, 54: 615-626. PMID:25503588. doi:10.1007/s40262-014-0221-7.

Vlachopoulos C, Ioakeimidis N, Abdelrasoul M, Terentes-Printzios D, Georgakopoulos C, Pietri P, et al. 2016. Electronic cigarette smoking increases aortic stiffness and blood pressure in young smokers. Journal of the American College of Cardiology, 67: 2802-2803. PMID:27282901. doi:10.1016/j. jacc.2016.03.569.

Wagener TL, Floyd EL, Stepanov I, Driskill LM, Frank SG, Meier E, et al. 2017. Have combustible cigarettes met their match? The nicotine delivery profiles and harmful constituent exposures of secondgeneration and third-generation electronic cigarette users. Tobacco Control, 26: e23-e28. PMID:27729564. doi:10.1136/tobaccocontrol-2016-053041.

Walele T, Sharma G, Savioz R, Martin C, and Williams J. 2016. A randomised, crossover study on an electronic vapour product, a nicotine inhalator and a conventional cigarette. Part B: safety and subjective effects. Regulatory Toxicology and Pharmacology, 74: 193-199. PMID:26702788. doi:10.1016/j. yrtph.2015.12.004.

Westenberger BJ. 2009. Evaluation of e-cigarettes. Food and Drug Administration, St. Louis, Missouri. pp. 1-8.

Wieslander G, Norbäck D, and Lindgren T. 2001. Experimental exposure to propylene glycol mist in aviation emergency training: acute ocular and respiratory effects. Occupational \& Environmental Medicine, 58: 649-655. PMID:11555686. doi:10.1136/oem.58.10.649.

Willershausen I, Wolf T, Weyer V, Sader R, Ghanaati S, and Willershausen B. 2014. Influence of E-smoking liquids on human periodontal ligament fibroblasts. Head \& Face Medicine, 10: 39. PMID:25224853. doi:10.1186/1746-160X-10-39.

Williams M, Villarreal A, Bozhilov K, Lin S, and Talbot P. 2013. Metal and silicate particles including nanoparticles are present in electronic cigarette cartomizer fluid and aerosol. PLoS ONE, 8: e57987. PMID:23526962. doi:10.1371/journal.pone.0057987.

Williams M, To A, Bozhilov K, and Talbot P. 2015. Strategies to reduce tin and other metals in electronic cigarette aerosol. PLoS ONE, 10: e0138933. PMID:26406602. doi:10.1371/journal. pone.0138933.

Wu Q, Jiang D, Minor M, and Chu HW. 2014. Electronic cigarette liquid increases inflammation and virus infection in primary human airway epithelial cells. PLoS ONE, 9: e108342. PMID:25244293. doi:10.1371/journal.pone.0108342.

Xue J, Yang S, and Seng S. 2014. Mechanisms of cancer induction by tobacco-specific NNK and NNN. Cancers, 6: 1138-1156. PMID:24830349. doi:10.3390/cancers6021138.

Yan XS, and D'Ruiz C. 2015. Effects of using electronic cigarettes on nicotine delivery and cardiovascular function in comparison with regular cigarettes. Regulatory Toxicology and Pharmacology, 71: 24-34. PMID:25460033. doi:10.1016/j.yrtph.2014.11.004.

Yingst JM, Veldheer S, Hrabovsky S, Nichols TT, Wilson SJ, and Foulds J. 2015. Factors associated with electronic cigarette users' device preferences and transition from first generation to advanced generation devices. Nicotine \& Tobacco Research, 17: 1242-1246. PMID:25744966. doi:10.1093/ntr/ ntv052. 
Yu V, Rahimy M, Korrapati A, Xuan Y, Zou AE, Krishnan AR, et al. 2016. Electronic cigarettes induce DNA strand breaks and cell death independently of nicotine in cell lines. Oral Oncology, 52: 58-65. PMID:26547127. doi:10.1016/j.oraloncology.2015.10.018.

Yuan M, Cross SJ, Loughlin SE, and Leslie FM. 2015. Nicotine and the adolescent brain. The Journal of Physiology, 593: 3397-3412. PMID:26018031. doi:10.1113/JP270492.

Zhu S-H, Sun JY, Bonnevie E, Cummins SE, Gamst A, Yin L, et al. 2014. Four hundred and sixty brands of e-cigarettes and counting: implications for product regulation. Tobacco Control, 23: iii3-iii9. PMID:24935895. doi:10.1136/tobaccocontrol-2014-051670. 